\title{
Legal and Regulatory issues Affecting Compressed Air Energy Storage
}

\author{
P. L. Hendrickson
}

July1981

Prepared for the US. Department of Energy under Contract DE-AC06-76RLO 1830

Pacific Northwest Laboratory Operated for the US. Department of Energy by Battelle Memorial Institute 


\title{
NOTICE
}

This report was prepared as an account of work sponsored by the United States Government. Neither the United States nor the Department of Energy, nor any of their employees, nor any of their contractors, subcontractors, or their employees, makes any watranty, express or implied, or assumes any legal liability or responsibility for the accuracy, completeness or usefulness of any information, apparatus, product or process disclosed, or represents that its use would not infringe privately owned rights.

The views, opinions and conclusions contained in this report are those of the contractor and do not necessarily represent those of the United States Government or the United States Department of Energy.

\author{
PACIFIC NORTHWEST LABORATORY \\ operated by \\ BATTELLE \\ for the \\ UNITED STATES DEPARTMENT OF ENERGY \\ Under Contract DE-AC06-76RLO 1830
}

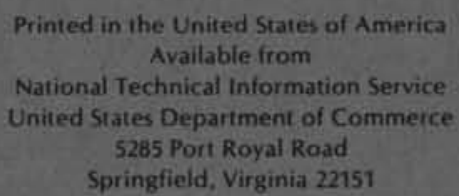

Price: Printed Copy $\$$ $\because$ Microfiche $\$ 3.00$

$\begin{array}{cc}\text { *Pages } & \begin{array}{c}\text { NTIS } \\ \text { Selling Price }\end{array} \\ 001-025 & \$ 4.00 \\ 026-050 & \$ 4.50 \\ 051-075 & \$ 5.25 \\ 076-100 & \$ 6.00 \\ 101-125 & \$ 6.50 \\ 126-150 & \$ 7.25 \\ 151-175 & \$ 8.00 \\ 176-200 & \$ 9.00 \\ 201-225 & \$ 9.25 \\ 226-250 & \$ 9.50 \\ 251-275 & \$ 10.75 \\ 276-300 & \$ 11.00\end{array}$


Paul L. Hendrickson

July 1981

Prepared for

the U.S. Department of Energy

under Contract DE-ACO6-76RLO 1830

Pacific Northwest Laboratory

Rich land, Washington 99352 


\section{SUMARY}

This document examines several regulatory and legal issues that can potentially affect implementation of a compressed air energy storage (CAES) system. This technology involves the compression of air using base load electric power for storage in an underground storage medium. The air is subsequently released and allowed to pass through a turbine to generate electricity during periods of peak demand. The storage media considered most feasible are a mined hard rock cavern, a solution-mined cavern in a salt deposit, and a porous geologic formation (normally an aquifer) of suitable structure. The issues are discussed in four categories: regulatory issues common to most CAES facilities regardless of storage medium, regulatory issues applicable to particular CAES reservoir media, issues related to possible liability from CAES operations, and issues related to acquisition of appropriate property rights for CAES implementation.

A variety of regulatory issues can potentially affect implementation of any CAES project. The focus in this document is on selected federal regulation. Lesser attention is given to state and local regulation. Conventional CAES systems rely on a liquid petroleum product or natural gas to preheat the compressed air before it enters the turbine, Use of these fuels will require an exemption from the Powerplant and Industrial Fuel Use Act. The CAES plant planned by the Soyland Power Cooperative, Inc. has recently received such an exemption. The air emissions that result from burning the fossil fuels must be controlled sufficiently to meet a11 regulatory requirements under the Clean Air Act. At a minimum this will involve meeting the Environmental Protection Agency (EPA) new source performance standard for gas turbines. Compliance with prevention of significant deterioration and nonattainment regulations under the Act may also be required, depending on the quantity of individual pollutant emissions and the ambient air quality at the CAES site.

Several regulatory concerns relate to water. A permit under the underground injection program created by the Safe Drinking Water Act will most likely be needed for any CAES system. Surface water discharges are not expected to be a serious problem with a CAES system, but a National Pollution Discharge Elimination System permit will still most likely be needed. Special 
precautionary measures may be required to minimize the possibility of oil spills at the site. The CAES operator will also need to comply with state law to obtain a supply of water for cooling, cleaning, sanitary, and other purposes. A limited number of wells will be needed for injection and monitoring for CAES systems using a cavern in hard rock or a salt deposit for air storage. In contrast, a large aquifer-based system may require up to several hundred wells. Compliance with applicable state and local well drilling, construction, and abandonment standards will also be necessary.

Certain miscellaneous regulatory concerns will also be applicable to any CAES system. An environmental impact statement will most likely be required either because a significant federal permit or other action is involved or because the facility is in a state having its own environmental policy act. A certificate of convenience and necessity and state concurrence in facility siting will be required in most states. Finally, the CAES owner/operator will have to comply with applicable health, safety, and noise regulations.

Additional regulatory concerns are applicable to CAES in particular storage mediums. The principal environmental and regulatory concern for CAES in a salt cavern will be disposal of the brine generated during cavern construction. Underground injection is the most probable disposal option, and will require an underground injection control permit. CAES in a hard rock cavern may involve compliance with special mining safety regulations during construction. Disposal of mine waste will require compliance with applicable state solid waste and surface mine regulations. Whether EPA regulations issued under the Solid Waste Disposal Act will be applicable is uncertain. An aquifer-based CAES system may require compliance with special state or local injection requirements designed to protect potable water. Siting may also be influenced by special use aquifer classifications.

Liability resulting from CAES operations is not likely, but can potentially arise in several different ways including cavern blowouts, induced seismic activity or subsidence, groundwater contamination, and accidents resulting from surface activities. If damage to third parties does occur, the CAES operator can potentially be held strictly liable regardless of any fault or negligence on the operator's part. Sound site selection, engineering, and purchase of appropriate insurance can help mitigate liability exposure. 
CAES projects can be located in relatively rural areas and purchase of needed property rights should therefore not be extraordinarily expensive, especially in relation to total project costs. Multiple landowners at the desired site or unwilling sellers may present difficulties. In some cases, the power of eminent domain may be available. Land requirements for surface activities should not exceed several hundred acres and may be as low as 100 acres for CAES in a salt deposit cavern. The CAES facility owner may also want to consider purchase of all land overlying the air storage zone to minimize the possibilities of outside interference and liability. In the case of CAES in an aquifer, this may require the purchase of up to 2000 acres or more. Purchase of an underground air storage easement underlying land not needed for surface activities is a possible alternative approach. 


\section{ACKNOWFDGMENTS}

The author wishes to thank the following PNL staff members who made valuable suggestions on earlier versions of this document: R. D. Allen, M. A. Beckwith, T. J. Doherty, and R. W. Reilly. Vicki Lee provided helpful editorial assistance. 


\section{CONTENTS}

SUMMARY

ACKNOMEDGMENTS

ACRONMS .

1.0 INTRODUCTION $\quad$ •

2.0 REGULATORY ISSUES COMMN TO MOST CAES FACILITIES . $\quad$ • $\quad 2.1$

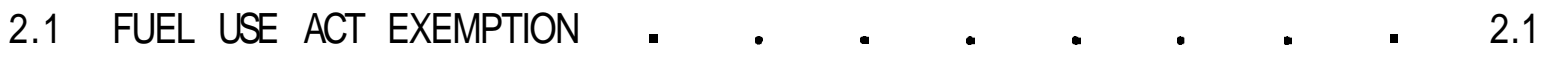

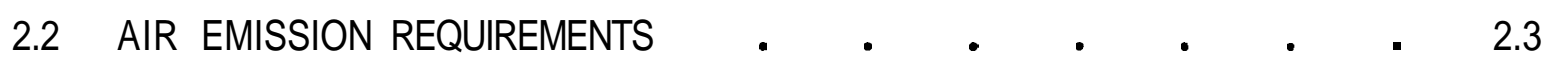

2.2.1 New Source Performance Standards . • • • 2.4

2.2.2 Prevention of Significant Deterioration

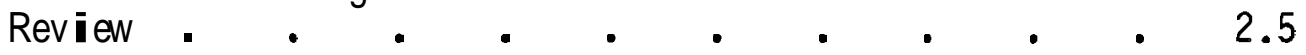

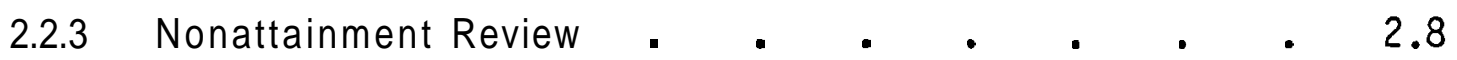

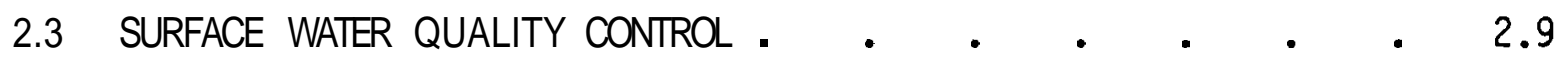

2.3.1 Sources of Water Pollutants . $\quad$ • $\quad$ • $\quad$ • 2.9

2.3.2 NPDES Permit . • • • • • • • • • 2.10

2.3.3 0il Storage • • • • • • • • . 2.11

2.3.4 Construction Activities $\quad$ • . . . . . 2.12

2.4 WATIR ACQUISITION • • • • • • • • • • • • 2.12

2.4.1 State Water Withdrawal Rights . . . . . 2.12

2.4.2 Dredge and Fill Permit . . . . . . . 2.13

2.5 PONG PLANT CERTIFICATION AND SITING • • • • • 2.13

2.5.1 Certification . . • • . . . . 2.13

2.5.2 State Siting Legislation . . . . . . 2.13

2.5.3 Federal Legislation . • • • • • • • 2.14

2.6 UNDERGROUND INJECTION REQUIREMENTS .

2.7 WE $\perp$ DRILLING AND CONSTRUCTION REQUIREMENTS • • • • 2.18 
2.8 ENVIRONMENTAL IMPACT STATEMENT REQUIREMENTS . • . . 2.18

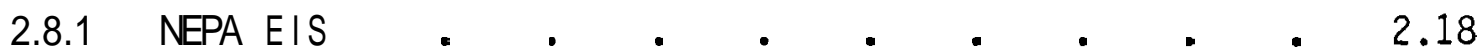

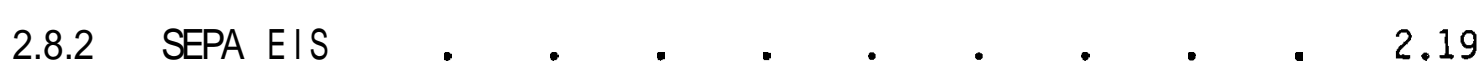

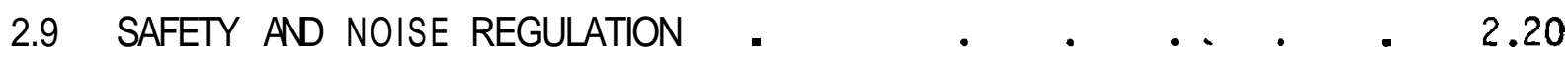

3.0 REGULATORY ISSUES APPLICABLE TO PARTICULAR

CAES RESERVOIR MEDIA $\quad$ • $\quad$ • $\quad$ • $\quad$ •

3.1 SALT DEPOSTS

3.1.1 Subsurface Brine Injection . • • • • • • 3.1

3.1.2 Ocean Brine Disposal . $\quad$ • $\quad$ • $\quad$ • 3.2

3.1.3 Land Brine Disposal . $\quad$. $\quad$ • . 3.2

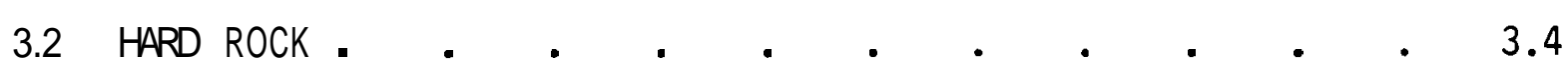

3.2.1 Safety Regulations . . . . . . 3.4

3.2.2 Mine Waste Disposal . . . . . • • . 3.5

3.2.3 Compensating Reservoir . • • • • • • 3.6

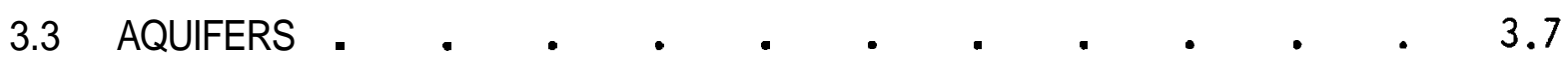

3.3.1 Special Injection Requirements . $\quad$ • $\quad$ • 3.8

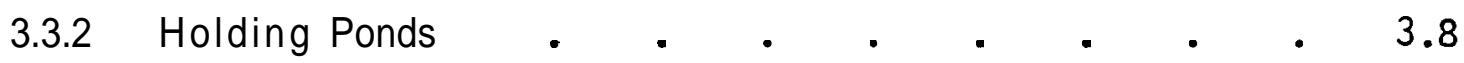

3.3.3 Special Aquifer Classifications . $\quad$ • $\quad$ • $\quad$ • 3.8

4.0 POTENTIAL LIABILITY .

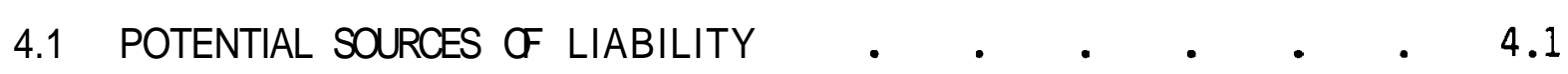

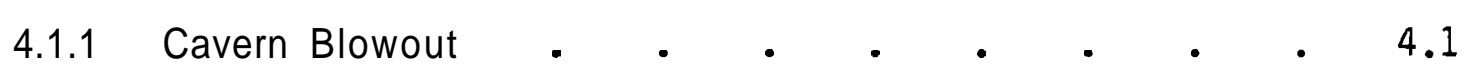

4.1.2 Induced Seismic Activity . $\quad$ • . 4.1

4.1.3 Groundwater Contamination . $\quad$ • 4.2

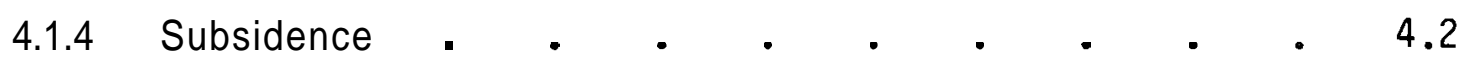

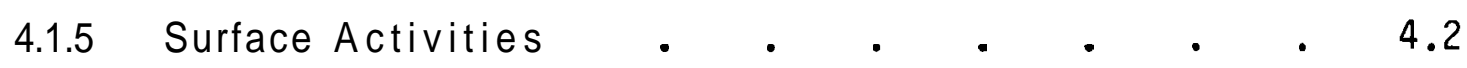

4.2 THEORIESFOR LIABILITY • • • • • • • • • • 


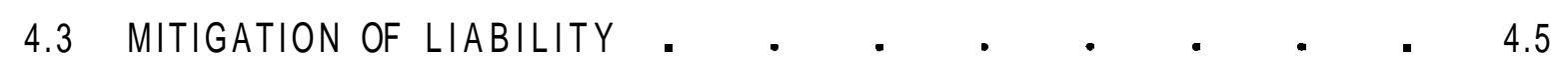

5.0 ACQUISITION OF PROPERTY FOR CAES IMPLEMENTATION • $\quad \boldsymbol{\cdot} 5.1$

5.1 PROPERTY RIGHTS NEEDED FOR STORAGE AND RECOVERY • 5.1

5.2 EXERCISE OF EMINENT DOMAIN • • • • • • • • • c 5.3

APPENDIX A - BACKGROUND INFORMATION ON GROUNDWATER LAW . A.I

APPENDIX B - BACKGROUND INFORMATION ON OWNERSHIP AND USE OF UNDERGROUND SPACE .

REFERENCES AND NOTES $•$ • 


\section{ACRONYMS}

CAA

CAES

aR

ONA

DOE

EIS

EA

EPRI

EA

FERC

FUA

MWe

NSHA

NEPA

NPDES

NTIS

OSHA

PSD

PN

RCRA

SDWA

SEPA

TES

tpy

UIC

USCA

USCPO
Clean Air Act

compressed air energy storage

Code of Federal Regulations

Clean Water Act

U.S. Department of Energy

environmental impact statement

U.S. Environmental Protection Agency

Electric Power Research Institute

Economic Regulatory Administration

Federal Energy Regulatory Commission

Powerplant and Industrial Fuel Use Act of 1978

megawatt electric

Mine Safety and Health Administration

National Environmental Policy Act

National Pollution Discharge Elimination System

National Technical Information Service

Occupational Safety and Health Administration

prevention of significant deterioration

Pacific Northwest Laboratory

Resource Conservation and Recovery Act

Safe Drinking Water Act

state environmental policy act

thermal energy storage

tons per year

underground injection control

United States Code Annotated

United States Government Printing Office 


\section{LEGAL AND REGULATORY ISSUES AFFECTING COMPRESSED AIR ENERGY STORAGE}

\section{$1.0 \quad$ INTRODUCTION}

The objective of this study is to examine significant legal related issues that can potentially affect implementation of the compressed air energy storage (CAES) concept in the U.S. The focus is on federal regulatory issues and on issues affecting liability and property rights. Lesser attention is given to state and local regulatory issues. The study examines selected issues believed to be important to implementation of the concept. The issues examined are certainly not exhaustive, however. Site specific issues, especially local regulations, clearly must be examined in depth prior to any implementation effort.

CAES is a relatively new concept for electrical energy storage by electric utilities. Electrical energy is stored by compressing large quantities of a ir and storing it in an underground storage reservoir. Compression is accomplished with off-peak base-load power that normally will be generated by coal and/or nuclear power plants. The stored air is later released in a controlled manner through a conventional turbine-generator to generate electricity during periods of peak demand. Compression and release cycles may occur once a day or even more often depending on load demand. A general schematic of a CAES cycle is shown in Figure 1.

The primary objective of CAES is to utilize relatively inexpensive baseload power more effectively to reduce overall generation cost and the need for peaking power generating units fired by expensive oil and natural gas. Secondary objectives are to provide an emergency standby power supply in case of failure at a power station or in the electricity transmission grid and to assist stabilization of the frequency of the alternating current.

A conventional CAES cycle will involve staged cooling of the compressed air before storage and reheating the air before it passes through the turbines. Cooling reduces the energy required for compression, the volume of the storage cavity, and the possibility of damage to the storage formation. The 


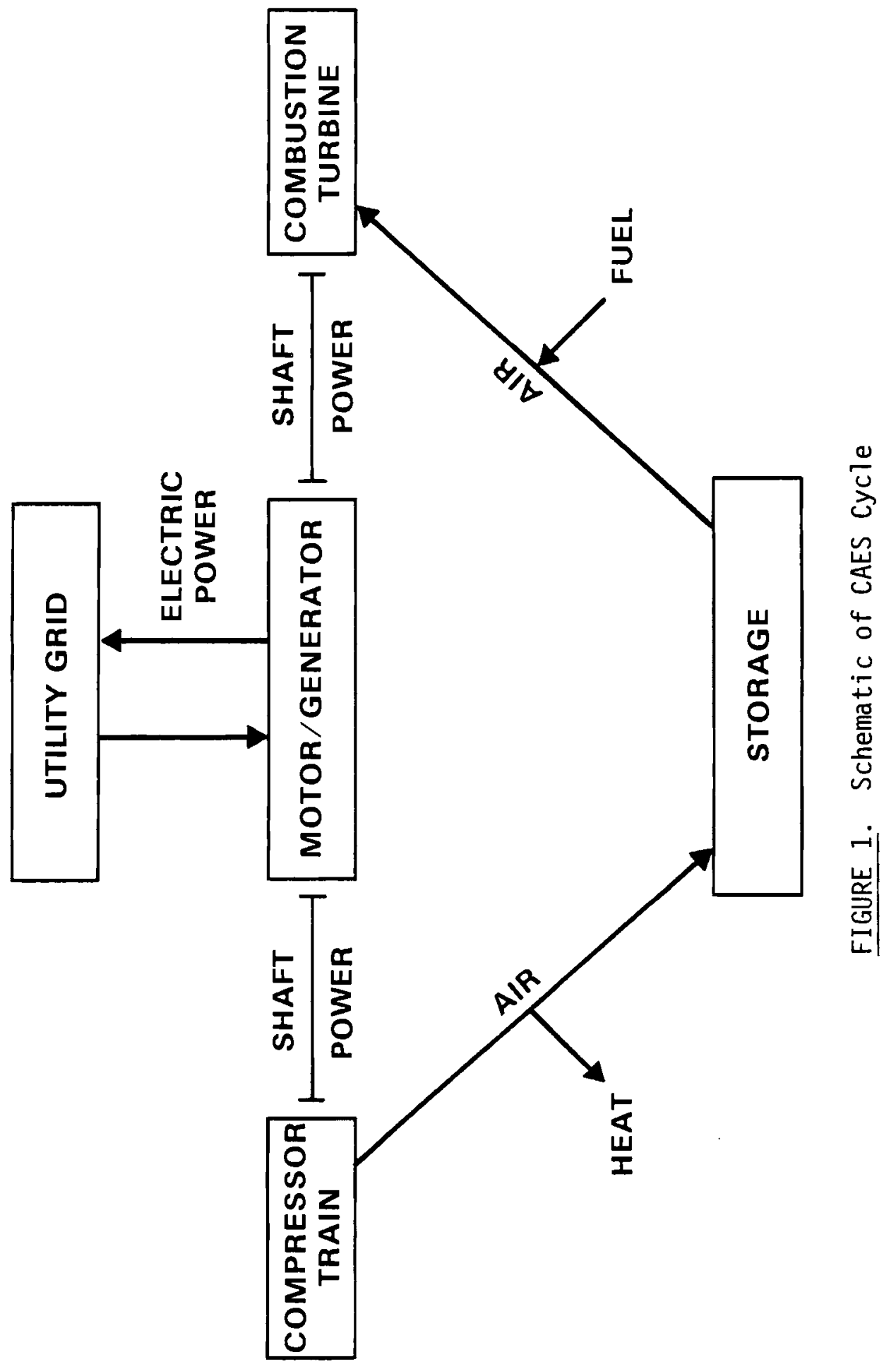


air is reheated after leaving the storage reservoir in a combustion unit that will probably be fired by a liquid petroleum product or natural gas. An option that does not require new technology and will most likely be implemented in most CAES applications is to use a recuperator to capture the waste exhaust heat from operation of the turbine to preheat the air coming from storage. If the compressed air is stored at a sufficiently low pressure, it can potentially be used without reheating by using low-pressure turbines; however, this approach results in relatively low system efficiency and high storage cost. Reheating the air in a combustion unit and subsequent expansion through the turbine increases power output and efficiency.

Conventional CAES systems using a combustion unit can be expected to save up to two-thirds of the oil or gas that would otherwise be needed to produce the same amount of peaking power with a conventional gas turbine. (1) Since the input air to a CAES turbine is already compressed, the energy content of the reheating fuel is largely devoted to performing useful work, namely electricity generation. In contrast, a conventional combustion turbine peaking unit must drive its own compressor stage, absorbing approximately two-thirds of the available fuel energy internally. By using base load electricity to compress and store air, the amount of fuel consumed to generate peak load electrical power can be substantially reduced.

Alternative CAES technologies that would reduce and perhaps even eliminate the need for oil and gas combustion are being studied. Alternate heat sources such as the combustion of coal in fluidized bed combustion ${ }^{(2)}$ or coal gasification units are possible but unproven candidates for reheating the stored air. Problems include system inefficiencies caused by frequent start-up and shut down and the need for further technical development. CAES coupled to thermal energy storage (TES) has considerable potential for reducing oil and gas consumption. In a CAES/TES system the heat generated during compression is stored in a pebble bed for later use in reheating the air after release from storage. This concept appears to be economically attractive in comparison to a conventional CAES system in many cases. (3) The more advanced CAES/TES systems are termed adiabatic if essentially no fossil fuels are required for reheating the air and hybrid if the need for fuel is reduced, but not eliminated. A hybrid 
system can potentially be further enhanced by using stored solar energy to preheat the air coming from storage.

Possible underground storage media for compressed air include caverns in salt deposits and hard rock formations, and natural water-bearing formations (i.e. aquifers). Generally, storage will be at depths of 1500-3000 feet. A salt cavern would most likely be solution mined and would have a long, vertical cylindrical shape. A more compressed cavern in a relatively thin salt deposit is also possible. Compressed air storage in hard rock would most likely be in a specially mined cavern, although previously mined and natural caverns are remote possibilities. A dome-shaped or closed anticlinal aquifer configuration is required for CAES in an aquifer to prevent migration of the compressed air away from the storage site. Groundwater at a sufficiently high discovery pressure to retain the stored air is needed beneath the air bubble. Aquifer storage is similar to the widely used natural gas storage technology.

The air stored in a hard rock cavern can be maintained at constant volume or constant pressure. Constant pressure is achieved through the use of a surface compensating water reservoir. The water level in the reservoir is allowed to fluctuate slightly to maintain a constant vertical head of water, and therefore constant hydrostatic pressure, in the air storage cavity. This-mode of operation has several advantages. First, the total design volume and hence the cost of the cavity is significantly reduced. Second, large pressure changes potentially damaging to the host rock are minimized. Finally, turbine efficiency is increased by air inflow at constant pressure. The compensating reservoir is less suitable for a cavern in a salt deposit primarily because the surface reservoir would necessarily have to be saturated with dissolved salts. This condition presents potentially large environmental problems related to disposal and clean-up of potential spills. No commercial salt deposit CAES projects with a compensating reservoir are known to be planned. A compensating reservoir is not needed for air storage in an aquifer because adequate buffer storage can be provided to minimize pressure traverse during operation and because providing adequate storage volume is not a significant portion of system capital cost.

The first and currently the only commercial CAES facility went into operation in December 1978 at Huntorf, West Germany. The facility is a 290 MWe unit 
and uses two 150,000 cubic meter solution-mined salt caverns for air storage. (4) A small-scale CAES field test in an aquifer is currently being constructed by the Pacific Northwest Laboratory (PNL) for the U.S. Department of Energy (DOE) near Pittsfield, Illinois, and several commercial CAES installations are in the planning stages. The Soyland Power Cooperative, Inc., of Decatur, lllinois, is planning to construct a 220 MWe CAES facility using a mined hard rock cavern and a surface compensating reservoir. DOE the Electric Power Research Institute (EPRI), and three investor-owned utilities are cosponsoring investigations into site specific applications of CAES in the U.S. (4) A study of an aquifer-based CAES system is being led by Public Service Indiana. An investigation of a CAES facility with a solutioned-mined cavern in a salt deposit as the storage medium was led by Middle South Services, Inc. A study of CAES in a mined hard-rock cavern with a compensating reservoir was led by Potomac Electric Power Co. Finally, the SEO utility group in Belgium is planning a CAES in hard-rock system.

The principal alternative to CAES with present technology is a pumped hydro storage installation. This technology involves pumping water into a reservoir at a higher elevation using off peak power. The water is later released to fall through the same pumps, now acting as turbines, to generate electricity during periods of peak demand. The turbines can either be at ground level with the water storage reservoir at a higher elevation, or the turbines can be underground with the storage reservoir at ground level. The latter approach is a relatively new concept, which is termed underground-pumped hydro. The approach has a relatively high capital cost, but has the advantages of being able to utilize a very high vertical head of water and providing siting flexibility. Aboveground-pumped hydro facilities have been used in the U.S. for fifty years, and about 35 such systems are either operating or are under construction with a total capacity of 25 gigawatts. (5)

The remainder of this document is organized into four sections. Section 2.0 examines regulatory issues common to most CAES systems in the U.S with any of the three possible storage mediums. Section 3.0 examines regulatory issues applicable to particular CAES mediums. Section 4.0 discusses possible areas of liability associated with a CAES operation. Section 5.0 discusses 
acquisition of property rights to implement a CAES system. Background information on groundwater rights and ownership of subsurface space is included in the appendices. 


\subsection{REGULATORY ISSUES COMMON TO MOST CAES FACILITIES}

The purpose of this section is to discuss regulatory considerations that are potentially applicable to the implementation of a CAES system in any storage medium. The focus is on federal regulatory considerations with secondary attention given to state and local requirements. The principal regulatory areas of concern are likely to be requirements under the Powerplant and Industrial Fuel Use Act (FUA) related to the combustion of oil or gas, air emission requirements, underground injection requirements, power plant siting legislation, and environmental impact statement (EIS) requirements.

\subsection{FUEL USE ACT EXEMPTION (a)}

Under section 201 of FUA, ${ }^{(6)}$ no new electric power plant may use natural gas or petroleum as a primary energy source unless exempted. For a conventional CAES facility, this restriction presents a potential problem because natural gas or petroleum will ordinarily be the fuel choice to reheat the stored compressed air prior to introduction into the turbine. The problem may not be burdensome because the Soyland Power Cooperative, Inc. has recently received a permanent fuel mixture exemption (see below) from the Act. (7) This exemption will most likely provide a precedent for future CAES applications requiring an exemption from the Act.

The term "primary energy source" is defined in section 103(b)(15) of the FUA simply as the fuel or fuels used by any new electric power plant. The primary fuel to produce the peaking power from a CAES facility in terms of percentage of Btu's supplied is the energy source at the base-load power plant that supplies the electricity to operate the compressor at the CAES facility. This base-load plant will generally be either coal or nuclear. However, according to the definition in the FUA, it is entirely possible that the natural gas or petroleum used at the CAES installation will be interpreted to be the primary fuel because it is the fuel used at the plant actually producing the peak load power. Fortunately, certain exemptions to the section 201 prohibition are provided for in sections 211-214 of the FUA. Final regulations relating to the

(a) DOE published a notice of proposed rule making on June 12, 1981, 46 Federal Register 31216, that will significantly simplify exemption procedures under FUA if the proposed changes are made final. 
exemptions were issued by the Economic Regulatory Administration (ERA) within DOE in dune 1980 and became effective August 5, 1980.(8)

Section 212 of the FUA provides for several categories of permanent exemptions from the section 201 prohibition. The exemptions that are most likely to be most suitable for a CAES facility are the exemption in section 212(d) for certain fuel mixtures that include gas or petroleum and the exemption in Section 212(g) for peak-load power plants.

The fuel mixture exemption is potentally available when an alternate fuel is used with natural gas or petroleum to produce electricity. In most cases the electricity used to compress the air will have been generated at a coal or nuclear power plant. If one of these base-load fuels is considered as part of the fuel mixture used to produce power at the CAES facility and this fact can be demonstrated, the fuel mixture exemption is potentially available. (9) Although in most cases the electricity will simply come from the grid, it should be possible to make the required demonstration on a system-wide basis. Additionally, the Btu heat input from the natural gas or petroleum at the CAES facility cannot exceed the minimum Btu heat input supplied by the base-load power plant. (9) Compliance with this requirement should not be difficult for a typical CAES installation, which typically will have a 2:1-3:1 ratio of energy supplied at the base load plant to energy supplied at the CAES facility.

Several informational requirements must be submitted to EPA in support of a fuel mixture exemption. (10) The requirements are extensive and must be studied with care. They include a complete description and engineering assessment of the fuel mixture, design specifications, a demonstration that no reasonable alternative source of electric power exists, a description of conservation measures designed to minimize oil or gas use, and an environmental impact analysis of the proposed and reasonable alternative sites. A demonstration that alternate fuels cannot be used is also required. (11) These requirements, further described at $10 \mathrm{CFR}$ 503, should be analyzed in detail prior to submitting an application to ERA for an exemption.

The other most probable exemption category is for peak-load power plants. To qualify for this exemption a petitioner must certify to ERA that the power plant will be operated solely as a peak-load plant for the life of the facil\$) If natural gas is to be used as the fuel source, the cognizant air 
pollution control agency must determine that the use of any alternate fuel would contribute to a condition in which a national air quality standard would be exceeded. (13) As with the fuel mixture exemption, several informational studies must be conducted to qualify for the peak-load power exemption. The required studies are similar to, but not identical to those required for the fuel mixture exemption. Several requirements are included:

- a demonstration that alternate fuels cannot be used at the proposed site and at reasonable alternative sites (10 CFR 503.11, 503.16)

- documentation of conservation measures (10 CFR 503.13)

- information on oil and gas consumption (10 CFR 503.14)

a an environmental impact analysis (10 CFR 503.15).

If the fuel mixture exemption or the peak-load power exemption fail to apply to a proposed CAES system, several other permanent exemption categories are possible. (14) Possibilities include an exemption for emergency purposes, maintenance of service reliability, inability to comply with applicable environmental requirements, and lack of alternate fuel supply. A temporary exemption can also be obtained if alternate fuels are more costly, site limitations exist, or environmental requirements cannot be met. ${ }^{(15)}$ The procedural requirements for filing an exemption petition with ERA are at 10 CFR 501 Subpart $\mathrm{F}$ and must be studied in detail before an actual petition is filed.

\subsection{AIR EMISSION REQUIREMENTS}

The source of air pollutants in a CAES facility is the natural gas or oil used to reheat the compressed air before it enters the turbine. If no gas or oil are used in an adiabatic system, a system that utilizes solar energy for reheating, or a low-pressure CAES system, little or no air pollution should occur and emission regulations are not relevant. When gas or oil are used, compliance with air quality and air emission requirements is potentially a complex process.

At a minimum, the EPA new source performance standard for stationary gas turbines and any applicable state requirements issued pursuant to a state implementation plan will have to be met. Also, most likely a permit under the EPA prevention of significant deterioration (PSD) regulations will be required or 
special requirements will be imposed if a proposed CAES facility is to be located in an area where any ambient air quality standard is being violated.

The basis for air pollution reguiation is the Clean Air Act of 1970 (CAA) as amended. Section 109 of the CAA ${ }^{(16)}$ directs EPA to promulgate primary national ambient air quality standards for individual air pollutants that specify levels of pollution that cannot be exceeded without threatening human health. Secondary standards are designed to prevent adverse effects on public welfare (e.g., vegetation and scenic values). To date EPA has promulgated primary national ambient air quality standards for sulfur dioxide, particulates, carbon moxoxide, nitrogen oxide, lead, hydrocarbons and ozone, (17) frequently referred to as criteria pollutants. The standards for ozone and hydrocarbons are enforced in conjunction with each other because hydrocarbons are considered to have an adverse effect only as they contribute to the formation of

ozone. (18) Secondary standards have been designated for sulfur dioxide and particulates. Section 110 of the CAA directs states to develop and adopt state implementation plans that set forth all necessary control efforts to achieve compliance with the national ambient air quality standards. The state implementation plans establish specific emission limits for various categories of air pollution sources, or in some cases, limits for individual sources, or emission limits by geographic area. To facilitate compliance with the national standards, EPA and the states have divided the country into 247 air quality control regions according to the direction provided in section 107 of the CAA.

\subsubsection{New Source Performance Standards}

Overlying the state implementation plans are the new source performance standards that section 111 of the CAA directs $巴 P A$ to promulgate. These standards apply to specified categories of new or modified stationary air pollution sources. New source performance standards have been issued for about 30 source categories, including stationary gas turbines. (19) $巴 A$ denied a petition to revise the gas turbine standard on December $11,1980 .(20)$ The stationary gas turbine standard applies to units with a heat input at peak load equal to or greater than 10.7 gigajoules per hour, which corresponds to a peak power output of about 2.5 MWe. Essentially all conventional CAES facilities will exceed this level and therefore be subject to the standard. Implementation and enforcement of the standards has generally been delegated to the states. Under 
its implementation plan, a state has the option of applying the new source performance standard as promulgated by EPA or adopting a more restrictive standard. In virtually all cases then, a CAES operator will require a permit from the cognizant state or local air pollution authority authorizing operation of the turbine in conformity with the EPA new source performance standard for gas turbines or a more restrictive state standard if one exists.

\subsubsection{Prevention of Significant Deterioration Review}

In addition to the new source performance standard, a CAES facility will also most likely have to comply with EPA regulations for prevention of significant deterioration and/or regulations for operation in nonattainment areas (i.e., areas where an ambient air quality standard is being violated). These regulations are complex and compli ance can be a time-consuming and costly process. Their potential application can only be summarized here.

New EPA PSD regulations were issued August 7, 1980. (21) Generally, any major new or modified stationary source is subject to the PSD regulations if the area is in compliance (attainment) or is unclassifiable with respect to at least one of the national ambient air quality standards. If applicable, the PSD regulations will require application of the "best available control technology" and preparation of pollutant-specific impact analyses.

A key element of the PSD requirements is the definition of a major air pollution source. According to the regulations, (22) a major source is a source that emits or has the potential to emit, after application of appropriate pollution control technology, 250 tons per year (tpy) or more of any pollutant subject to the CAA. ${ }^{(23)}$ These pollutants include the criteria pollutants plus the following noncriteria pollutants: asbestos, beryllium, mercury, vinyl chloride, florides, sulfuric acid mist, total reduced sulfur compounds, and hydrogen sulfide. It is entirely possible that a large CAES installation will emit or have the potential to emit 250 tpy or more of a criteria pollutant. An illustration is provided by the CAES installation being investigated by Potomac Electric Power Co. The conceptual plant will have four turbines, a capacity of 1000 MWe, and will use number 2 fuel oil for reheating the compressed air. Below are the estimated total emissions ${ }^{(24)}$ for the four turbines in tpy, assuming 10 hours per day ${ }^{(25)}$ and 365 days/year operation: 


$\begin{array}{lr}\text { sulfur dioxide } & 329 \\ \text { particulates } & 77 \\ \text { carbon monoxide } & 219 \\ \text { hydrocarbons } & 77 \\ \text { nitrogen oxides } & 612\end{array}$

Under these conditions, PSD review would most likely apply to sulfur dioxide and nitrogen oxide emissions.

The states are required to update and revise their implementation plans to comply with the PSD regulations. If EPA approves the proposed plan, the state can implement its own PSD program; otherwise, EPA will implement the program.

If a CAES facility is determined to be subject to PSD review, several important requirements apply. First, the facility must have the "best available control technology" installed to control the emission of each pollutant with the potential to emit 250 tpy or more. What constitutes this technology is generally negotiated with the cognizant regulatory authority. ${ }^{(26)}$ At a minimum, the new source performance standard must be met.

A second requirement of PSD review is that the impact on ambient air quality of each criteria pollutant emitted that is subject to PSD review must be analyzed. (27) This requirement may involve monitoring the air quality of criteria pollutants for up to a year preceeding the PSD permit application if such data are not otherwise available. Modeling of air quality impacts on noncriteria pollutants subject to the CAA will also be required. ally, the air pollution source applicant will have to demonstrate how much of the available PSD increment the facility will consume. The PSD increment is the amount of additional pollution that may be allowed in a particular area. The amount of available increment is determined by baseline air quality, the national ambient standards and the classification of the area. Geographic areas are classified in decreasing order of desired air quality as $\mathbf{I}$, II, or III. Areas are generally classified by the states, except that certain areas such as parks are permanently designated in section 162(a) of the CAA as Class I - Available increments for sulfur dioxide and for particulates are designated 
in section 163 of the CAA. Available increments for other criteria pollutants are under investigation by EPA. ${ }^{(29)}$

A third requirement of PSD review is that the applicant must conduct an air quality analysis for all pollutants that are regulated under the CAA and which the proposed CAES facility has the potential to emit in "significant" amounts. ${ }^{(30)}$ Note that this requirement applies to all pollutants regulated under the CAA, not simply to criteria pollutants with the potential to emit 250 tpy or more. Significant amounts are defined ${ }^{(31)}$ to be rates of emission (in tpy) that equal or exceed the following:

$\begin{array}{lc}\text { carbon monoxide } & 100 \\ \text { nitrogen oxides } & 40 \\ \text { sulfur dioxide } & 40 \\ \text { particulates } & 25 \\ \text { ozone } & 40 \\ \text { lead } & 0.6 \\ \text { asbestos } & 0.007 \\ \text { beryl lium } & 0.0004 \\ \text { mercury } & 0.1 \\ \text { vinyl chlorides } & 1 \\ \text { fluorides } & 3 \\ \text { sulfuric acid mist } & 7 \\ \text { hydrogen sulfide } & 10 \\ \text { total reduced sulfur } & 10 \\ \text { reduced sulfur compounds } & 10\end{array}$

The air quality analysis requires monitoring of criteria pollutants, ${ }^{(32)}$ and modeling for noncriteria pollutants. (33)

A fourth requirement of PSD review is analysis of the impairment to visability, soils, and vegetation that would occur as a result of the facility and associated commercial and residential growth in the surrounding area. (34) Finally, the PSD permit application calls for a variety of information relating to the proposed facility including its location, operating specifications, construction schedule, emissions, and emission controls. (35) 
One way to avoid PSD review is to keep all criteria pollutant emissions below the 250 tpy cut-off. A second possibility is to limit the breadth of PSD review by limiting the number of criteria pollutants that have the potential to exceed $250 \mathrm{tpy}$. The potential CAES operator may want to give serious attention to both of these possibilities.

\subsubsection{Nonat Review}

If a proposed CAES facility is to be located in a geographic area where the existing concentration of a criteria pollutant exceeds the national ambient air quality standard (i .e., the area is nonattainment with respect to the pollutant), the nonattainment permit and review procedures must be followed. (36) These procedures apply only to sources with the potential to emit 100 tpy of a criteria pollutant in geographic areas where the same pollutant exceeds ambient standards. (37) It is important to note that analysis must be done on each individual pollutant. One pollutant from a particular CAES facility could potentially be subject to the nonattainment review procedures. A second pollutant could be subject to both PSD and nonattainment review. A third pollutant from the same facility could be subject to the PSD review process only if the ambient concentration of this pollutant is within the applicable air quality standard.

If nonattainment review applies to a particular criteria pollutant, several important requirements must be met. First, the applicable state implementation plan must be in the process of being carried out. In areas that are nonattainment, this means a plan for reaching attainment status must be in effect. If the state plan to reach attainment is inadequate or is not being carried out, a construction moratorium on all new air pollution sources may be in effect. Second, the lowest achievable emission rate must be achieved for the nonattainment pollutant. This level of emission cannot be higher than the new source performance standard and will be subject to negotiation with the appropriate regulatory agency. Third, the applicant must demonstrate that all other air pollution sources owned by it within the state are in compliance with air pollution regulations or are on a compliance schedule. A final requirement is that the applicant must comply with the emissions offset rule. If an area is nonattainment for any criteria pollutant, a state can accommodate new 
sources by requiring reductions in emissions for the nonattainment pollutant from existing sources sufficient to create a margin of air quality within ambient standards to permit new sources. Or the state can require a new applicant to achieve sufficient offsets (i.e., reductions in emissions from other sources) to more than make up for the emissions to be generated by the new source.

The nonattainment permit and review requirements can potentially be as burdensome as the PSD requirements. The potential CAES operator may want to seriously investigate whether the emission of criteria pollutants that are nonattainment for the specific geographic area can be kept below 100 tpy to avoid this review.

\subsection{SURFACE WATER QUALITY CONIROL}

The discharge of water pollutants into virtually any surface water body will most likely require a National Pollution Discharge Elimination Permit (NPDES). Permits required under section 401 of the Clean Water Act (CWA) (38) can be obtained from either the Regional $\square A$ Administrator or the state water quality agency, whichever operates the program. At least 33 states have now received EPA authority to operate the NPDES system within their border. (39) Discharges without a permit are illegal. (40) The only exception to this requirement would occur if discharge is through a sewer to a treatment works with its own NPDES permit. To do this the CAES operator must meet the EPA pretreatment regulations at $40 \mathrm{CP} 403$, comply with state and local law, and meet the discharge rules of the treatment works operator.

\subsubsection{Sources of Water Pollutants}

Sources of water pollutants include blowdown discharge from a compensating reservoir, thermal and chemical pollutants in cooling tower blowdown, sanitary wastes, storm water drainage, oily wastes from fuel and oil drains where the turbomachinery is housed, fuel storage and transfer facilities floor service drainage, and water separated from the air before and/or after compres-

sion. (41) The oily wastes will most likely be separated into oil and water wastes. The oil wastes and possibly the residue from the fuel o il tank can be collected and transferred to an oil rerefiner. Sanitary wastes will likely be discharged to a septic system or to a sewer if one is available. 
Most CAES systems will have to reject some heat to the atmosphere and in blowdown even if thermal energy storage is attempted. Heat is specifically included within the definition of pollutants in the CWA. (42) The greatest amount of heat will be generated during the compression cycle. Excess heat from the air coolers and heat generated by mechanical and electrical losses must be dissipated. During power production, reject heat from the turbine exhaust and again from electrical and mechanical losses must also be dissipated. Ordinarily, a wet cooling tower will be the selected means for heat dissipation. A wet/dry or a dry system, although more expensive, are alternate possibilities in water-short areas. The 220 MWe CAES system under investigation by Middle South Services uses both wet and dry cooling. Cooling water flows will be as high as 35,000 gallons per minute during the compression cycle and 10,000 gallons per minute during power generation. (43)

\subsubsection{NPDES Permit}

Any discharge of pollutants to navigable waters will require an NPDES permit. Navigable waters are defined in the CWA as the waters of the United States including the territorial seas. (44) Waters of the U.S. are defined at 40 CFR 122.3 to include virtually all surface water bodies. NPDES permits include interim and final effluent limitations, a compliance schedule to achieve final effluent limitations and self-monitoring and reporting requirements. ${ }^{(45)}$ The final effluent standard in the NPDES permit will require the more stringent of the following: (46)

1. limitations necessary to meet the water quality standards of the receiving waters under sections $301(b)(1)(c), 302$, or 304 of the CWA, or any more stringent state standard, or

2. (a) the best conventional pollutant control technology (47) must be applied to conventional pol lutants (biochemical oxygen demand, total suspended solids, pH, fecal coliform, and oil and grease). (48)

(b) the best available technology for al1 nonconventional pollutants. (49)

These requirements must be met by July 1, 1984, and consequently would effectively apply to any new CAES facility in the U.S. Interim effluent 
requirements prior to July 1, 1984, require the application of the best practicable control technology currently available. (50) The necessary equipment and control technologies to meet these standards will ultimately be determined by negotiation with the cognizant regulatory authority.

A potentially useful negotiating point regarding thermal discharges for the CAES operator is section 316 of the CWA. This section authorizes the state or EPA, as appropriate, to set the thermal component of any discharge permit at a level that "will assure the protection and propagation of a balanced, indigenous population of shellfish, fish, and wildlife in and on" the water body. Protection beyond this level is not required.

In addition to the effluent requirements described above, any cooling water intake structure in navigable waters will require a permit from the U.S. Army Corps of Engineers. (51) EPA requires that the structure reflect "the best technology available for minimizing adverse environmental impact. "(52)

\subsubsection{Oil Storage}

A conventional CAES facility using oil for reheating the compressed air will have oil storage tanks. If the oil could possibly pollute a surface water body after an accidental spill, special regulatory requirements may have to be met.

Section 311 (b)(3) of the CWA prohibits discharge of oil or hazardous substances in harmful quantities into the navigable waters of the U.S, adjoining shorelines, or the contiguous zone. A harmful quantity is any discharge that will violate applicable water quality standards or cause a film or sheen upon the water surface or adjoining shoreline. ${ }^{(53)}$ Even a very small discharge will produce a film and hence be a harmful quantity. The scope of protection extends to essentially all surface water bodies. ${ }^{(54)}$

The EPA regulations applicable to oil pollution prevention are found at 40 CFR 112. They apply to all oil consuming activities unless: 1) the geographic location of the facility is such that an accidental oil spill could not reach a surface water body, or 2) the underground buried storage capacity of the facility is 42,000 gallons of oil or less, or 3) the surface storage capacity does not exceed 1320 gallons and no single oil container has a capacity exceeding 660 gallons. (55) If the above exemptions are not applicable, a 
variety of precautionary design and operating steps must be taken. These precautions include appropriate containment and diversionary structures and provisions for inspection of equipment and record keeping. The precautionary steps must be documented in a spill prevention control and countermeasure plan that has been certified by a professional engineer. (56) The plan must be available for EPA review during business hours.

\subsubsection{Construction Activities}

Water pollution from construction activities related to a CAES facility may be subject to regulation under local or state law. Section 208 of the CWA $(57)$ provides a procedure for areawide waste management treatment. The geographic area and a planning/regulatory agency is to be designated by the state governor. Any plan prepared under this process must include provisions to control construction activity sources of pollution, (58) and the disposal of pollutants on land or in subsurface excavations. (59) Investigation into whether such an agency has been designated and its regulatory requirements should precede any construction activity.

\subsection{WATER ACQUISITION}

\subsubsection{State Water Withdrawal Rights}

In nearly all western states and many eastern states, a permit from the state water resources agency will be required to obtain water for cooling or other purposes. (60) This requirement applies to either surface water or groundwater. In addition, separate permits will most likely be needed if any water body is dammed, has its course altered, or is otherwise affected.

Western states generally follow the appropriation system for acquiring surface and groundwater rights. A permit to withdraw water will usually be granted if the state agency determines that the proposed use will not interfere with the rights of existing users of waters drawn from the water body, that unappropriated water is available, and that the project is not otherwise contrary to the public interest.

Eastern states generally follow the riparian system of water law. Under this system an owner of land contiguous with a surface water body may ordinarily use a reasonable amount of the water in a beneficial way. Many eastern 
states (e.g. Delaware, Florida, Iowa, Kentucky, Maryland, Mississippi, New Jersey, North Carolina, and Wisconsin) also require a permit to utilize surface water. A lesser number of eastern states require a permit for groundwater withdrawals.

\subsubsection{Dredqe and Fill Permit}

In addition to a state permit to withdraw water, a permit from the U.S. Army Corps of Engineers may be required if any dredging or filling activities in a wet land area or surface water body is needed for placement of a water intake structure or otherwise. The authority for the permit requirement is section 404 of the CWA. Applicable regulations are at 33 CFR 323.

\subsection{POWER PLANT CERTIFICATION AND SITING}

\subsubsection{Certification}

A CAES facility will probably require a certificate of convenience and necessity prior to construction if the facility is to be located in a state that normally requires such a certificate for new power generating stations. Certificates are required for new generating facilities added by investor-owned utilities in approximately 35 states and for publicly owned utilities in approximately 16 states. ${ }^{(61)}$ Certificates are required for major transmission line additions in approximately 37 and 18 states, respectively.

\subsubsection{State Siting Legislation}

A proposed CAES facility may have to meet siting requirements at both the local and state level of government. At the local level, zoning requirements must be met. Preemption of local requirements by a state siting agency is unusual, and local requirements must normally be met in addition to state requirements. (62)

Forty two states now have some form of state role in power plant siting. ${ }^{(63)}$ The siting legislation follows a general pattern, but details differ from state to state. The general thrust of the legislation is to coordinate state regulatory efforts and designate a single agency to play the lead role in issuing whatever construction permit and/or certificate of convenience and necessity is needed for final state approval. 


\subsubsection{Federal Legislation}

Although the federal government does not directly participate in the power plant siting decision process, several federal laws are indirectly applicable. The National Environmental Policy Act (NEPA), (64) discussed in section 2.8.1, is most likely to have impact in nearly all CAES siting decisions. The Fish and Wildlife Coordination Act requires consultation with the Fish and Wildlife Service whenever any body of water is to be impounded, directed, or modified in any manner. (65) Any CAES facility needing a federal permit that is to be located in a coastal zone must furnish certification to the permitting agency that the facility will comply with the state's coastal zone management program. These programs generally were formulated in response to the Coastal Zone Management Act of 1972 . (66) A list of other federal legislation that can potentially affect the siting process is in the Tenth Annual Report of the Council on Environmental Quality. (67) Licensing by the Federal Energy Regulatory Commission could conceivably be required for a CAES facility with a compensating reservoir, however, this result seems unlikely (see section 3.2.3).

\subsection{UNDERGROUND INJECTION REGU IREMENTS}

Most likely every CAES facility will require an underground injection control (UIC) permit issued by EPA or a state water quality control agency authorized by EPA to operate the UIC program. The authority for the UIC program is Part C of the Safe Drinking Water Act of 1974 (SDWA). (68) The Act directs EPA to promulgate regulations limiting the underground emplacement of fluids by well injection that may contaminate any underground water that supplies or can reasonably be expected to supply any public water system. ${ }^{(69)}$ The Act contemplates that regulatory programs wi 11 be administered by the states under procedures established by EPA. EPA has broadly interpreted its Congressional mandate and has prohibited any underground injection unless authorized by permit or rule by the cognizant regulatory authority. (70) The UIC program is only recently being implemented. Final regulations for the program were issued by EPA on May 19, 1980, (71) and are found at $40 \mathrm{CFR} 122.31-122.45$ and $40 \mathrm{CFR}$ 146. State requirements applicable to establishing acceptable UIC programs are found at $40 \mathrm{CFR}$ 123, Subparts $\mathrm{A}$ and $\mathrm{C}$. In addition to requirements under the 
UIC program, certain states also have existing underground injection requirements. These requirements may eventually merge with or be superseded by regulations under the SDWA.

EPA has utilized the discretion provided it in the SDWA and determined that all states will be subject to the UIC regulations. (72) All states must submit an approvable UIC program to EPA by April 1981 or request an extension not to exceed 9 months; otherwise EPA will establish a program for the state.

Underground injection is defined in section 1421(d)(1) of the SDWA to be the subsurface emplacement of fluids by well injection. The definitions of "fluid" and "well injection" are important in determining application of the SDWA to CAES. Although the SDWA does not define the term'fluid," the EPA regulations define it to include any gas. (73) Well injection is defined to be "the subsurface emplacement of fluids through a bored, drilled, or driven well or a dug well where the depth of the dug well is larger than the largest surface dimension." Thus, even injection through the four-foot inside diameter air pipe that is planned for air injection and withdrawal at the hard rock CAES facility being investigated by Potomac Electric Power Co, ${ }^{(74)}$ appears to be well injection within the meaning of the EPA regulations. Under these definitions, any CAES facility presumably will be subject to the UIC regulations.

In the criteria and standards that EPA has promulgated at $40 \mathrm{CFR} 146$ implementing the UIC program, five injection well classifications are established ${ }^{(75)}$ and injection practices included within classes I-IV are defined. All wells not included within these classes are lumped into class V. If, as seems likely, the air injection portion of a CAES facilty is determined to be subject to the UIC regulations, it will almost certainly be a class $\mathrm{V}$ injection well. This classification includes wells that inject nonhazardous fluids into or above formations that contain underground sources of drinking water. (76) The examples for class $\mathrm{V}$ wells given in the regulations $(77)$ do not include air or gas injection; however, the list is stated to be illustrative only.

The UIC regulations provide for four separate types of underground injection authorization: authorization by rule, individual permits, area permits, and emergency permits. Injection into class $V$ wells may be authorized by rule 
indefinitely, provided that applicable existing and future regulatory requirements are met. (78) Authorization by permit is regulated under the requirements at $40 \mathrm{CFR}$ 122.38. A CAES injection well authorized by rule must still obtain a permit unless authorization by rule was for the life of the well. (79) A permit for a class $\mathrm{V}$ well may be issued for a fixed term not to exceed 10 years. (80) An areawide permit for multiple wells in a limited geographic area is authorized under $40 \mathrm{CFR}$ 122.39. This provision is especially applicable to aquifer-based CAES systems that may require as many as several hundred wells in a single well field. Emergency permits are authorized at $40 \mathrm{CFR}$ 122.4, although this provision would probably not be applicable to a CAES project.

The technical requirements applicable to class $\mathrm{V}$ wells are found at $40 \mathrm{CFR}$ 146 Subpart F. The regulations direct owner/operators of these wells to submit a description of any existing well and its status to the state within one year of the effective date of a state UIC program. Within three years of the effective date, the state must submit to EPA information on the construction features of class $V$ wells and the nature and volume of injected fluids, an assessment of their contamination potential, available corrective actions and their economic and environmental consequences, and recomendations for regulatory action. (81) Final construction requirements for underground injections from class $V$ wells thus will probably not be issued for three to four years .

Even though Subpart $\mathrm{F}$ does not impose construction requirements on class $\mathrm{V}$ wells at this time, certain regulations are applicable. These requirements are effective when a state UIC program is approved by EPA or when EPA establishes a UIC program for the state. General conditions applicable to all UIC and NPDES permits are found at $40 \mathrm{CFR}$ 122.7. These conditions establish certain duties, such as the duty to mitigate environmental damage and to allow inspections by regulatory officials. Another limitation is that no class $V$ injection well shall be authorized by rule or permit if the well will allow the movement of any fluid containing any contaminant into underground sources of drinking water $(82)$ when the presence of the contaminant may cause a violation of any primary drinking water regulation under $40 \mathrm{CFR} 142$ or may adversely affect pub: lic health. ${ }^{(83)}$ Various sanctions can be applied if a potential violation 
from an operating class $V$ well is detected. The following requirements, found at $40 \mathrm{CR}$ 122.41, are also applicable to any injection well authorized by permit:

(1) all records concerning the nature and composition of the injected fluid must be retained

(2) the cognizant UIC regulatory official must be notified

(a) whenever any contaminant may endanger an underground source of drinking water or may cause fluid migration into or between underground sources of drinking water

(b) 180 days prior to conversion or abandonment of the injection we 11.

(3) injection may not begin until construction is complete and the cognizant UIC regulatory agency has been notified and given an opportunity to inspect the well.

Under $40 \mathrm{CR} 142.42(\mathrm{f})$, a permit for a class $V$ well may include conditions to ensure that plugging and abandonment of the well will not allow the movement of fluids that will adversely affect drinking water supplies. Finally, under 40 CR 122.42(g) a performance bond or other form of financial guarantee may be required by the cognizant regulatory authority to assure proper abandonment of the well. From the CAES facility owner's stand point, the most desirable authorization thus appears to be authorization by rule for the life of the project. A regulatory authority obviously may or may not want to confer this type of authorization.

Certain states also have their own permit requirements related to underground injection. Eventually these requirements may merge into the requirements under the SDWA however, in the interim they must be identified and complied with. For example, any injection well in Illinois, the site of the PNL field CAES test, must be approved by the State Environmental Protection Agency. A permit from a cognizant state or local health authority may be needed in any state if any possibility exists that public drinking water supplies will be affected by a CAES project. Also, a CAES facility possibly will be regulated at the state level similarly to an oil or natural gas well. Such things as an engineering and geology study and an injection plan could be required. (84) 
Finally, an NPDES permit for the a ir injection portion of the CAES operation should not be required because only discharges of pollutants without a permit are prohibited by the $\mathrm{OAA}^{(85)}$ and air is not within the scope of pollutant as defined in the Act. ${ }^{(42)}$

\subsection{WEL DRILLING AND CONSTRUCTION REQUIREMENTS}

All CAES facilities will require the construction of at least one air injection/withdrawal shaft. A CAES facility with a pressure-compensating reservoir will require at least two shafts. A CAES system utilizing aquifer storage may require up to a hundred wells or even more for a large system to adequately inject into, withdraw from, sample, and monitor the aquifer. Many states have well drilling, construction and abandonment regulations ${ }^{(86)}$ and compliance with these regulations most likely will be necessary.

Some state requirements go into considerable detail and may cover such areas as information needed for a permit, well location, well design and construction, well drilling equipment and materials, pumps and related equipment, testing, maintenance, and abandonment. (87)

Most states license well drillers. Some states have inspection requirements and require that log data and/or a well completion report be filed. Chemical and bacteriological analyses may also be required.

\subsection{ENVIRONMENTAL IMPACT STATEMENT REQUIREMENTS}

An environmental impact statement (EIS) most likely will need to be prepared prior to construction of a commercial CAES facility. The EIS will be required by NEPA, by a state environmental policy act (SEPA), or both. The NEPA requires federal agencies to prepare a detailed EIS for each major federal action significantly affecting the quality of the human environment. (88)

\subsubsection{NEPA EIS}

Two questions must be answered before determining of whether an EIS under NEPA would be required for any particular CAES project. The first question is whether a major federal action is involved. A typical CAES facility will require an exemption from the FUA from DOE-ERA. The facility may require a permit from EPA for air or water discharges or underground injection if the 
respective programs are not being operated by the state. A permit from the Corps of Engineers may be needed if a cooling water intake structure is placed in a surface water body or in a wetland area. Also, a CAES facility possibly could be located on land leased, exchanged, or purchased from a federal agency or federal funds or loan guarantees could be utilized in financing the CAES facility. Any of these federal actions could possibly trigger the NEPA requirement for an EIS. The second question is whether the environmental impacts of the CAES project are significant. Impacts may be significant even if on balance there is a positive environmental impact. Given the extent of environmental impacts that were described earlier in Section 2.0 and that will arise during the construction and operation of a CAES facility, a CAES project of more than minimal size will probably be construed to have significant impacts.

A federal agency may decide to prepare an environmental assessment if it is unclear whether an EIS should be prepared, to facilitate preparation of an EIS, or to aid an agency's compliance with NEPA when no EIS is necessary. (89)

When more than one federal agency will be involved in the NEPA process, the agencies must determine which one will be the lead agency and which will be cooperating agencies. ${ }^{(90)}$ A state agency involved in the NEPA process because of the existence of a SEPA may act as a joint lead agency with a federal agency. ${ }^{(91)}$ The Council on Environmental Quality will appoint a lead agency if agreement cannot be reached. (92) It is difficult to predict in advance which federal agency would be the most likely lead agency if a CAES facility is determined to require preparation of an EIS.

\subsubsection{SEPA EIS}

A SEPA EIS possibly could be required for a CAES facility as over half of the states now have some type of state EIS requirement. (93) A variety of permit requirements, including an air or water discharge permit, a certificate of convenience and necessity to construct the facility, a UIC permit, or a request for a zone change, could potentially trigger the need for a SEPA EIS.

Both a NEPA and a SEPA EIS would probably not be required because federal agencies are to cooperate with state and local governments to coordinate EIS 
preparation and eliminate duplication. (94) Moreover, many states specify that an otherwise necessary SEPA EIS will not be required if an adequate NEPA EIS has been prepared.

If either a NEPA or a SEPA EIS is prepared, the CAES plant owner will most likely have to prepare either a comprehensive environmental analysis and report or a draft EIS, either of which will be used by the regulatory agency to issue the final ElS.

\subsection{SAFETY AND NOISE REGULATION}

The construction and operation of a CAES facility will be subject to the safety regulations of the Occupational Safety and Health Administration (OSHA). Regulations applicable to construction activities are found at 29 CF 1926, while regulations applicable to operation of a CAES facility are found at 29 OR 1910. The OSHA regulations are enforced either by OSHA or by a state health and safety agency that has been delegated enforcement responsibility by OSHA.

The OSHA regulations applicable to noise control are of particular concern. (95) sources, the most important of which include turbine operation, the air inlet to the compressor, and cooling tower operation if a tower is used.

(96)

The OAHA noise regulations are applicable to the work environment. Many states and local governments also have noise regulations applicable to the general environment. (97) These regulations vary in scope and detail, but their potential applicability should be determined prior to construction. 


\subsection{REGULATORY ISSUES APPLICABLE TO PARTICULAR CAES RESERVOIR MEDIA}

\subsection{SALT DEPOSITS}

A salt deposit is one of the potential storage mediums for application of CAES technology. Utilization of a salt deposit will ordinarily involve solution mining a cavern of suitable size and geometry. Caverns may be developed in either salt dome or bedded salt deposits. An existing cavern previously mined for salt extraction can also potentially be used if the cavern and site are compatible with the utility's needs. The Huntorf, West Germany, CAES facility, which is the first commercial facility in the world, utilizes two approximately cylindrical solution-mined caverns in a salt deposit for air storage.

The principal environmental impact and also the most likely area of regulatory concern associated with construction is disposal of the brine produced by solution mining. Each cubic meter of storage cavern is expected to result in 7-10 cubic meters of brine requiring disposal. (98) The salt-dome cavern planned for air storage in the conceptual study conducted by Middle South Utilities provides air storage capacity of nearly 1.18 million cubic meters for the 220 MWe facility. ${ }^{(99)}$ A location near Carmichael, Mississippi, is planned.

The available brine disposal options include underground injection, ocean disposal, and ponding/evaporation. The last technique offers the possibility of commercial recovery of the salt. Underground injection will probably be the least expensive alternative, however, and is the planned brine disposal option at the Carmichael site.

\subsubsection{Subsurface Brine Injection}

Subsurface brine injection will probably be the least expensive disposal option, and in most cases, the option with the least environmental impact. The most important regulatory impact is the need for an injection permit under the UIC program. The permit must be obtained from the state water quality agency or the Regional EPA Administrator, whichever administers the program.

A brine disposal well will be classified as a class III well. (100) Standards applicable to class III wells are found at 40 CFR 146.31. Detailed 
information on the injection well, the nature of the brine, and the injection formation will most likely be required to support a permit application. The well must be cased and cemented and detailed well logs will be necessary. Well monitoring requirements may also be imposed if drinking water or water potentially suitable for drinking can be affected.

\subsubsection{Ocean Brine Disposal}

Ocean brine disposal can be done from a land-based point discharge source or by barging the brine to an acceptable ocean disposal site. Discharge from a point source on land will require an NPDES permit ${ }^{(101)}$ from the state water quality agency or the Regional EPA Administrator, whichever administers the NPDES program. Criteria to be used in issuing permits have recently been issued by EPA $(102)$ and essentially provide that a permit may be issued if the discharge will not cause unreasonable degradation of the marine environment. Certain conditions may be placed on a permit, and a monitoring program in the area of discharge is mandatory. (103)

If barge transport followed by ocean disposal is selected, a disposal permit from the Regional EPA Administrator under the Marine, Protection, Research, and Sanctuaries Act of $1972^{(104)}$ will be required. Applicable EPA regulations are found at $40 \mathrm{OR}$ Subchapter $\mathrm{H}$. A detailed application must be submitted and a public hearing may be required if objections to issuance of the permit are raised. Criteria for the evaluation of permit applications are found at 40 CFR 227. Acceptable ocean disposal sites are listed at 40 CFR 228. Disposal at other than approved sites may be proposed in the permit application. (105)

\subsubsection{Land Brine Disposal}

If the CAES facility owner elects to discharge the brine to a holding pond or lagoon, the EPA solid and hazardous waste regulations must be considered. The principal legislation to consider is Subtitle $C$ of the Solid Waste Disposal Act, otherwise known as the Resource Conservation and Recovery Act of 1976 (RCRA). (106) RCRA directs EPA to issue standards governing all aspects of hazardous waste control. It is not entirely clear whether salt brine would be considered a hazardous waste under the Act, ${ }^{(107)}$ and thus subject to the complex EPA hazardous waste regulations found at $40 \mathrm{CF}$ 261-265. Brine does not 
fit into the RCRA exclusion category at $40 \mathrm{CP} 261.4(\mathrm{~b})$. However, brine is not among the listed hazardous wastes in Subpart D of $40 \mathrm{CF} 261$. Brine may or may not be classified as a hazardous waste based on the characteristics of hazardous waste found in Subpart $\mathrm{C}$ of $40 \mathrm{CR} 261$. The characteristics are ignitabi1ity, corrosivity, reactivity, and toxicity. If a waste meets the test for any one characteristic, it is considered hazardous. Each characteristic has associated parameters and tests. The corrosivity test is probably most applicable to salt brine.

Brine ponding would, however, have to meet the criteria for solid waste disposal facilities and practices at $40 \mathrm{CR} 257$. The regulations at Part 257 were adopted under Subtitle D of RCRA. The definition of solid waste at $40 \mathrm{CR}$ 257.2 includes solid, liquid, and semisolid material resulting from industrial, commercial, and mining operations. The criteria in Part 257 provide that disposal shall not be in a floodplain, threaten endangered species, cause a discharge to surface water, or contaminate groundwater. The population of disease vectors must be minimized. Compliance with certain safety requirements is also necessary.

Prior to selecting land-based disposal, a detailed test of the brine should be made to determine whether it has any of the characteristics of hazardous waste as defined in $40 \mathrm{CR} 261$ Subpart $\mathrm{C}$. If the brine is found to be a hazardous waste, the regulations at $40 \mathrm{CR} 264$ and 265 applicable to owners and operators of hazardous waste treatment, storage, and disposal facilities must be met. The regulations at $40 \mathrm{CR} 265$ Subpart $\mathrm{K}$, relating to surface impoundments, will be especially applicable. If the brine is found to be hazardous, these regulations would also be applicable to any surface impoundment of brine that occurs prior to underground injection or ocean disposal.

If a brine spill from a holding pond occurs and the brine contains a "reportable quantity" of any of the 299 compounds designated as hazardous at 40 CR 116.4, the CAES operator could potentially be liable for a monetary penalty under section 311 of the CWA. The list of hazardous compounds is not identical to the list of hazardous wastes under RCRA at $40 \mathrm{CF}$ 261.3. The amount of each substance that constitutes a reportable quantity is given at 40 CR 117.3. Notice of any spil1 of a reportable quantity of a hazardous 
substance must be immediately given to the appropriate agency of the U.S. Government, which normally wil1 be EPA or the Coast Guard.

\subsection{HARD ROOK}

Compressed air storage in a natural or mined hard-rock cavern presents several unique regulatory considerations that merit attention. These considerations include safety regulations, regulations applicable to disposal of mined waste products, and considerations applicable to operation of a pressurecompensating reservoir.

\subsubsection{Safety Requlations}

The workers involved in the construction of a mined air storage cavern will either be subject to the safety regulations of the Mine Safety and Health Administration (MSHA) or the OSHA regulations discussed in section 2.9. Both of these agencies are in the U.S. Department of Labor. In some cases, safety regulations of each agency may apply.

Mine safety is regulated under the provisions of the Federal Mine Safety and Health Act of 1977. (108) The Act applies to any mine "the operations or products of which affect commerce." (109) Since the operation of a hard rock CAES mine results in electricity that almost certainly affects comerce, the provisions of the Act are most likely applicable to the construction of a CAES cavern. The definition of "mine" in the Act $(110)$ is also broad enough to potentially subject the disposal of mine waste and the construction and operation of a surface compensating reservoir to the provisions of the Act. The Act grants the Secretary of Labor the power to assign safety enforcement responsibilities to OSHA or MSHA in cases where the jurisdiction of these agencies may over lap. (111)

Occupational health and safety regulations adopted under the Federal Mine Safety and Health Act and potentially applicable to construction of a CAES cavern are found at $30 \mathrm{CR} 57$. A wide variety of activities are regulated under Part 57 including fire prevention, air quality in the mine, use of explosives, drilling, personal protection, materials storage, and safety programs. The regulations at $30 \mathrm{CR} 57.5$ relating to air quality, ventilation, and radiation protection merit particular attention. For example, a rock formation 
selected for a CAES cavern could possibly contain radionuclides or asbestiforms in quantities sufficient to cause a potential health hazard. (112) The regulations at 30 CR 57.5 potentially apply to both surface waste disposal operations and subsurface cavern construction operations.

\subsubsection{Mine Waste Disposal}

Disposal and long-term care of the waste and rubble resulting from construction of a hard-rock CAES facility will present certain technical and regulatory problems that must be considered. The size of the potential wastepile is significant. One study states that a large hard-rock CAES facility could produce waste rock covering 40 acres or more to a depth of 17 feet. (113)

It is not certain which of the EPA solid waste regulations will apply to waste product disposal. Most likely the criteria for solid waste disposal facilities and practices at $40 \mathrm{CR} 257 \mathrm{will}$ apply, and the hazardous waste regulations under RCRA at $40 \mathrm{CR} 261-265$ and the guidelines for the land disposal of solid waste at $40 \mathrm{CR} 241 \mathrm{w}$ ill not apply.

The criteria at 40 CR 257 (see section 3.1.3) do not apply to "overburden resulting from mining operations intended for return to the mine site. "(114) The waste from a CAES hard-rock cavern is not strictly overburden; however, it is the functional equivalent. The waste may or may not remain at the CAES site. Possibly the waste will have value as a construction or fill material in some cases and will be relocated. Otherwise the waste will most likely remain at the site because of high transport costs and the difficulty of finding an alternative storage site. If the waste remains at the CAES site, it will remain on the surface and not be placed in an excavated area as the overburden exemption apparently contemplates. The applicability of the part 257 regulations is therefore unclear. Since these regulations are not likely to be burdensome, good practice suggests that compliance should be achieved.

The hazardous waste regulations issued under RCRA also exclude mining overburden returned to the mine site. (115) Recent regulations also exclude solid waste from the extraction, beneficiation, and processing of ores and minerals. (116) The waste from a hard-rock CAES cavern probably wi11 be 
excluded from the hazardous waste regulations on the basis of one of the exclusions or because it does not exhibit any of the characteristics of hazardous waste found at Subpart $C$ of 40 CR 261.

EPA has also published guidelines for the land disposal of solid waste that are mandatory for federal agencies and recommended to state and local bodies. However, these regulations do not apply to mining "because of the lack of sufficient information upon which to base recommended procedures. "(117)

Several states do have solid waste disposal and surface mine reclamation requirements that may be applicable to hard-rock CAES waste disposal. (118) For example, in California the Surface Mining and Reclamation Act(119) of 1975 applies to surface mining operations and to surface disturbance associated with underground mining. A regulation adopted by the State Mining and Geology Board applicable to mined waste piles provides as follows: ${ }^{(120)}$

Permanent piles or dumps of mine waste rock and overburden shall be stable and not restrict the natural drainage without suitable provisions for diversion. Stable slopes at angle of repose shall be permitted as a final slope. Old equipment and other similar inert mining wastes shall be removed or buried. Toxic materials shall be removed or protected to reduce leaching to allowable levels. Under some conditions, covering of part or all of the mine waste may be desirable. Where reasonable choices exist, dumps shall be located in least visible locations. Controlled placement of this material with relationship to topography, hydrology, and end use features can greatly enhance the results of a reclamation program.

These requirements are illustrative of requirements that may be imposed in any state.

One of the significant environmental problems associated with a surface waste pile is control of sediment in runoff. Construction of a sedimentation pond may be needed or required. Such a pond qualifies as a point discharge source under the CWA and any discharges from the pond may require a NPDES permit.

\subsubsection{Compensating Reservoir}

As discussed in the Introduction, a hard-rock CAES cavern can be combined with a surface compensating reservoir to keep the stored air at constant pressure. The compensating reservoir will require an initial filling with water 
and periodic replenishing to replace system losses. Many of the regulatory concerns addressed in section 2.4 on water acquisition will be applicable to acquiring water for the reservoir. In practice, water requirements for cooling and the compensating reservoir can be treated as a combined requirement and a single permit from the appropriate regulatory agency obtained. A surface compensating reservoir ordinarily wi 11 not discharge water, and consequently no NPDES permit should be needed.

The possibility has been raised that a CAES facility with a compensating reservoir may require a license from FERC. (121) Section $23(\mathrm{~b})$ of the Federal Power Act ${ }^{(122)}$ requires a FERC license for the construction, operation, and maintenance of dams, water conduits, reservoirs, power houses, transmission lines, or other project works on or affecting navigable water which are necessary or convenient to the improvement of navigation or generation of water power. A key requirement is that the license is required for the generation of electricity by water power. A FERC license is not required for a steamgenerating plant that uses water only as a coolant. ${ }^{(123)}$ A license has often been required, however, for a pumped hydro installation because it does generate power from falling water. The compensating reservoir associated with a hard rock CAES facility is only incidental to the generation of electricity. It is used to improve system efficiency and operation, but it is not necessary for electricity generation. Consequently, it appears that an FERC license would not be needed. If there is doubt, a utility can file a petition with FERC for a declaratory order requesting a determination that a license is not requ i red. (124)

\section{3 $\underline{\text { AQUIFERS }}$}

Aquifer storage is the third storage medium under consideration for the CAES technology. Regulatory issues are considered in three categories: special injection reguirements, holding ponds, and special aquifer classifications. Aquifer storage of compressed air does not directly involve the withdrawal of groundwater during operation. Some withdrawal will be necessary though for such needs as sampling and testing of groundwaters, and in situ evaluations of caprock and reservoir rock. In many states a permit for groundwater withdrawal will be needed. Background information on groundwater law is included in Appendix A. 


\subsubsection{Special Injection Requirements}

In addition to the underground injection requirements discussed in section 2.6, use of an aquifer for CAES may require compliance in certain states with special regulatory requirements designed to protect groundwater. Special requirements are especially likely if the aquifer proposed for storage is a potential drinking water source. Minnesota, for example, prohibits underground injection wells unless a variance is obtained from the State Department of Health. (125) Groundwater protection, monitoring, and reporting requirements are likely conditions to a variance. In general, aquifers suitable for CAES are not likely to be potable water sources because they will be too deep and total dissolved solids content will be too high.

\subsubsection{Holding Ponds}

Prior to implementation of an aquifer-based CAES system, detailed well testing will be required. One necessary test is the aquifer pumping test conducted to ensure that the caprock has adequate integrity and to measure in situ permeability. (126) A temporary holding pond containing on the order of 50 acre-feet of water/brine will be required for the test. The discussion in section 3.1.3 applicable to land disposal of salt brine is pertinent to the regulatory requirements potentially applicable to the holding pond.

\subsubsection{Special Aquifer Classifications}

Utilization of an aquifer for CAES that has been designated by EPA or possibly a state agency as the sole or principal drinking water source for an area may be more difficult than utilizing an aquifer not so designated. The EPA has authority under section 1424(e) of the Safe Drinking Water Act to designate sole source aquifers. Once it has made a designation, no subsequent commitments of federal financial assistance may be made to projects that EPA determines mav contaminate the aauifer so as to create a significant hazard to public health. (127) Federal financial assistance is broadly defined to include contracts, grants and loan guarantees. (128) A significant hazard to public health is one that causes an aquifer to exceed any maximum contaminant level established by the National Primary Drinking Water Standards, (129) adversely affects human health, or requires additional treatment by a public 
water system to prevent adverse effects. As of July 1980, 7 aquifers had been designated as sole source and 8 petitions for sole source status were under consideration by EPA. ${ }^{(130)}$ The 7 aquifers designated as sole source are the Edwards Aquifer near San Antonio, Texas; the groundwater system of Guam; the aquifer beneath Fresno, California; the Magothy Aquifer underlying Nassau and Suffolk Counties on Long Island, New York; the Spokane-Rathdrum Aquifer in Washington and Idaho; the Biscayne Aquifer in southeastern Florida; and the Buried Valley Aquifer system of western Essex and Southeastern Morris Counties, New Jersey. (131)

In the future all groundwaters may be classified in some manner. Such a classification could affect where a CAES facility utilizing an aquifer for air storage could be located. EPA is currently considering a three-tiered groundwater classification system ${ }^{(132)}$ in which different levels of groundwater protection would be required for each classification. Three classifications are being considered:

1. groundwater that serves a highly valuable use or ecological function warranting the most stringent level of control

2. groundwater potentially usable as drinking water and requiring usual levels of protection

3. groundwater areas where limited and defined contamination would be all owed for certain contaminants.

Incentives would most likely be offered to encourage states to adopt the classification system ultimately selected. Certain states already have groundwater classification systems and associated water quality standards. Examples include New York, New Jersey, New Mexico, Maryland, and Minnesota.(133) 


\subsection{POTENTIAL LIABILITY}

The objectives of this section are to identify selected aspects of a CAES operation that can potentially lead to liability and to discuss the legal theories under which liability might be imposed. None of the events that could lead to possible liability can be considered likely. Nevertheless, the prudent CAES operator will want to be aware of potential liability sources in order to take steps to mitigate its possibility and perhaps to obtain appropriate insurance.

\subsection{POTENTIAL SOURCES OF LIAB ILITY}

Several potential liability sources are associated with a CAES operation. Some of the more important sources are highlighted below. More detailed survey studies are available, (134) and detailed investigations of particular environmental problems that can potentially lead to liability are becoming available as part of the three DOE-EPRI-utility studies on CAES applications that are discussed in the Introduction, and the Compressed Air Energy Storage Technology Program being managed by PNL for the Assistant Secretary for Conservation and Renewable Energy, DOE.

\subsubsection{Cavern Blowout}

A possible and very undesirable potential liability source is a blowout of the air storage cavern. This phenomenon could be caused by a loss of integrity between well casing and grout in any type of CAES injection well. Air leakage from the well or from the storage cavern in general can potentially lead to a sufficient pressure build up in air pockets below the surface that results in a blowout. In a reservoir compensated system, a blowout can also potentially be caused by the "champagne effect," whereby a two-phase air bubble-water mixture is forced out of the reservoir shaft.

\subsubsection{Induced Seismic Activity}

Induced seismic activity caused by daily air pressure cycling is a remote liability source, but one with potentially high consequences. Little is currently known about the likelihood of this possibility and the potential magnitude of activity and effects. The likelihood can be minimized by careful site 
selection and control of the pressure exerted on underground strata. Location at a site without minor faults or discontinuities may be difficult, however.

\subsubsection{Groundwater Contamination}

A CAES facility can potentially contaminate or otherwise damage groundwater in several ways. The risk of liability is especially great if the groundwater damaged is an existing or potential source of potable water. When an aquifer is utilized for air storage, chemical contamination can be induced by introduction of oxygen and carbon dioxide. Contamination can be enhanced by the heat of compression, which will warm the reservoir to some extent. Improper casing or inadequate chlorination can damage groundwater quality. An aquifer can also be contami nated by the introduction of microorgan isms. These effects can harm the CAES operation by reducing aquifer permeability and increasing equipment corrosion rates. Damage to other aquifer users or potential users is also possible.

Other damage to groundwater can occur no matter what type of air storage medium is used. Air escaping from CAES can potentially mix with natural gas and lead to groundwater contamination. Escaping air can also potentially alter artesian flow and the capacity of existing wells.

\subsubsection{Subsidence}

Ground subsidence is another low probability source of liability, but one that merits much attention. It can potentially be induced by construction of the underground air storage chamber, material fatigue caused by temperature and pressure cycling, and by mineral solubility enhanced by CAES operations.

\subsubsection{Surface Activities}

Potential liability can result from several surface-related activities. Drilling and injection activities and fossil fuel handling are possible liability sources. Examples include oil spills or damage caused by noise and vibration. These activities are fairly routine though, and liability is not likely if ordinary care is taken. Transport and disposal of hard-rock cavern waste or salt brine are less conventional activities and present a greater risk. Liability can result from such things as spills affecting adjacent lands, erosion precipitated by CAES activities, and contamination of surface water bodies. 
Any of the above phenomena can result in significant physical damage to the CAES facility and possibly to the manpower employed there. If the CAES facility is unable to operate for a period of time while repairs are being made, expensive peaking power will have to be generated or purchased elsewhere. Beyond these important concerns, the possibility of damage and consequent liability to third parties residing in the vicinity of the CAES facility exists. Damage could take the form of a contaminated or diminished capacity well or possibly physical damage caused by a blowout, induced seismic activity, or subsidence.

\subsection{THEORIES FOR LIABILITY}

A variety of different legal theories can potentially lead to liability in a particular situation. These theories include strict liability, negligence, nuisance, trespass, breach of a duty imposed by a statue or regulation, and willful misconduct.

The CAES operator would possibly be held strictly liable for any injuries or damage resulting from the CAES operation regardless of whether he was at fault. Injuries to any employee of the CAES owner/operator would be handled on a no-fault basis under the usual state workmen's compensation scheme. For damage to third parties, liability would most likely be based on the theory that strict liability should be imposed for escaping inanimate forces from

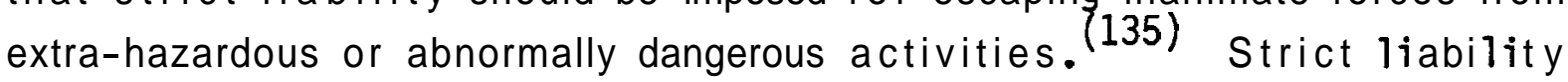
for injuries resulting from abnormally dangerous or non-natural activities stems from the 1868 English case of Rylands V. Fletcher. Most states have now accepted the theory. Under the theory, liability can be imposed without proof of negligence. The activity of a CAES operation (i.e., underground storage of air under pressure) probably would be considered by a court to be abnormally dangerous and hence the CAES operator should be strictly liable for damage to others. For example, in a California case ${ }^{(136)}$ a driller was held to be liable when his drilling, even though apparently careful, resulted in a blowout that damaged nearby property.

An injured plaintiff might also claim liability based on the theories of negligence, nuisance, or trespass. In practice, all of these theories plus strict liability might be pleaded. An action based on the negligence of the 
CAES operator would attempt to show his failure to meet an obligation or duty to conduct his operations in a manner to protect others against unreasonable risks. The plaintiff in such an action would have to show that failure to meet this duty of obligation led to his actual loss or damage. (137)

A nuisance theory is a flexible theory available to a plaintiff damaged by a CAES operation. A nuisance is a substantial harm to a right of another and is classified either as public or private. A public nuisance is an unreasonable interference with a right common to the general public. A private nuisance is unreasonable interference with the use and enjoyment of a property right (a groundwater right is a property right). To constitute a nuisance, the interference must be substantial and unreasonable. Intentional or negligent interference need not be shown. It is often difficult to predict whether a particular activity will cause substantial and unreasonable harm. However, the case law suggests that the presence of the following elements will increase the likelihood of recovery: (138)

1. The harm is continuous or produces long-lasting effects.

2. The harm would have been incurred by anyone in the plaintiff's position (i.e., the plaintiff is not peculiarly vulnerable).

3. The plaintiff's use of his property right preceded the CAES operation.

All of these elements need not be present for the plaintiff to prevail. Significantly, recovery under a nuisance theory may be possible even if the CAES operator is complying with all applicable regulations and permits.

The trespass theory is likely to be least helpful to a plaintiff. In appropriate cases, however, the theory can support and in effect coexist with a negligence and/or nuisance theory. The basis of the theory is an intentional invasion of the plaintiff's interest in the exclusive possession of property. (139)

A plaintiff can seek a variety of remedies in a case where damage is claimed, and a court has wide discretion to select among the remedies sought. A comnon remedy is to award monetary damages. If the defendant's activity is permitted to continue when the harm is very likely to be continuous, the 
result, in effect, is a judicially conferred power of eminent domain on the CAES operator. Another option is to force the defendant to add additional equipment or operate in such a manner that damage is reduced. In appropriate cases, the remedies can be combined.

\subsection{MITIGATION OF LIABILITY}

A CAES operator can take steps to minimize the possibility of future liability. Naturally the first step is to gain as much information as possible prior to implementation and construction about the technology, the air storage medium, and potential risks prior to implementation and construction. Sound design and engineering based on this information is the best protection against possible liability. A second obvious precaution is to purchase appropriate liability insurance. One study has determined that aboveground construction and operational aspects and underground construction aspects of CAES technology are familiar operations and should not present insurance difficulties. (140) The operational aspects of underground CAES are less familiar but analogies in coverage provided for underground storage of oil and natural gas exist. Although specific rates would necessarily have to be determined on a site and technology specific basis, the study concludes that the risk exposure from CAES technology is such that utilities will find that conventional insurance coverage will be available.

Beyond the steps of good design and engineering and obtaining adequate insurance coverage, other specific means exist to minimize the possibility of liability that the CAES operator might consider. Examples are suggested below.

One step would be to take water samples from all nearby wells prior to operation. (141) This step would serve the dual function of informing the CAES operator of existing groundwater quality and may also help to clarify any later disagreements on alleged degradation caused by the CAES operation. This step seems especially prudent with an aquifer-based CAES system, but also may be wise for hard-rock or salt-deposit based systems.

A second step to mitigate possible future liability is to provide written notice of the CAES operation to everyone holding an interest in the land utilized by the CAES facility. This step should be taken for test sites and sites 
abandoned after use. Notice of the CAES operation should be given to existing owners and any transferees of the utility. Ideally, notification should be recorded in any document of transfer or separately in the appropriate county land records so that constructive notice of the CAES operation is provided to future owners. Notice should reduce the possibility of any future claim of damage based on "hidden defects" resulting from the CAES operation. Section 353 of the Restatement of Torts (Second) ${ }^{(142)}$ provides that a vendor of real estate is under a duty to disclose to the vendee any concealed conditions that are known to him and that involve an unreasonable danger to the health or safety of those upon the premises, and which he may anticipate that the vendee will not discover. One example danger is the concern some have if a storage medium previously used for CAES testing or operation is subsequently used for natural gas storage. Trapped air can apparently form an explosive mixture, in some cases when mixed with natural gas. (143) A second example danger is iliustrated by the accident that occurred in November 1980 when an oil drilling rig punctured a salt mine shaft under Lake Peigneur in Louisiana, sending much of the 1.5 acre lake down the drill hole. ${ }^{(144)}$

A third possible mitigating step is to consider the purchase of all land potentially affected by the CAES operation. Land not needed for surface operations could then be leased for activities unlikely to be affected by the CAES operations.

Another step is to consider the cost effectiveness of lining surface brine holding reservoirs. This step would be costly, but would substantially reduce the possibility of liability resulting from spills. 


\subsection{ACQUISITION OF PROPERTY FOR CAES IMPEMENTATION}

\subsection{PROPERTY RIGHIS NEEDED FOR STORACE AND RECOVERY}

In addition to obtaining necessary regulatory permits, the CAES owner also requires assurance that he has the right to store, protect, and recapture the compressed air energy resource. H must also determine whether property interests should be purchased to reduce the possibility of future liability. The real property rights that must be acquired to achieve these objectives are the subject of this section. Background information on the ownership of underground space is included in Appendix B.

The extent of property rights that should be purchased will not always be clear, although it most likely will depend on several factors including the extent of perceived liability, how the bundle of ownership rights to the desired land has been broken up, the applicable state law and the extent of uncertainty in the law, and the relative cost of acquiring desired property rights. Complicating factors such as multiple owners and/or unwilling sellers can occur. In most cases, the CAES owner/operator will be able to obtain the desired property rights, although the acquisition process may be slow.

One advantage of a CAES power generating system is that it does not necessarily have to be located near a base-load power plant or a load center. Because the location can be selected using several decision criteria (one of which wi 11 naturally be electric power transmission cost), relatively inexpensive rural land may be selected for a CAES operation. In this case, acquisition of desired property rights may be relatively inexpensive, especially in comparison to total project costs. The time investment and the public relations aspect of acquiring land may thus be as important as the purchase cost. Ordinarily land needed for the site would be purchased outright. Whe the desired quantity of land is not available and/or there are multiple owners and unwilling sellers, consideration of options other than outright purchase may be warranted.

The bundle of property rights associated with a surface parcel of land can be divided in various ways. If the landowner retains all possible property rights, he is said to have a fee simple absolute interest. Out of this 
interest he can carve out such interests as easements, leaseholds, mineral rights, ${ }^{(145)}$ air space rights, and future interests in the property.

The minimum property right the CAES owner/operator will need to acquire is sufficient surface rights for physical access; injection, withdrawal, and observati on we 11s; compressors and power generating equipment; holding ponds; and transmiss'ion lines. Ordinarily this will involve purchase of a fee simple property interest sufficiently large to accommodate all of these needs. The desired interest can also possibly be obtained by purchasing an easement or through a long-term lease agreement. In all cases the right to drill wells and the assurance that the acquired property rights extend into the future at least as long as the project's planned life must be included. If acquisition of the surface right will interfere with a prior lease agreement or the implied surface access interest of a mineral estate holder, surface access must also be purchased from these parties.

In most cases, the CAES owner/operator will also want to acquire the groundwater and mineral rights for all land over the air storage medium. This acquisition is desirable principally to eliminate possible interference with CAES operations. A second reason is to reduce the possibility of future liability for such things as alleged groundwater contamination. In exceptional cases the mineral rights ma be too difficult to acquire or ma be considered worthless or dormant. In this situation the potential risks of nonpurchase can be weighed against the difficulty or futility of purchase.

In actual practice the CAES owner/operator wi 11 probably want to purchase a fee simple interest for all land overlying the air storage medium and any additional land needed for surface activities. This purchase should be entirely feasible for CAES in salt deposits and hard rock, where the total land required should not exceed several hundred acres. For aquifer storage, total land requirements can potentially be on the order of two thousand acres. In this case, alternatives to fee simple purchase ma want to be considered either to save money and/or because the total required land cannot be obtained for some reason. One possible alternative would be the purchase of an underground air storage easement for land utilized for air storage but not needed for surface activities. A second alternative would be to negotiate a long-term lease agreement with the surface owner and possibly the mineral estate holder. The 
storage rights for land where drilling could adversely affect the CAES project may also be considered for acquisition. The easement or lease would ordinarily be structured to include a covenant by the transferor/lessor not to utilize groundwater or conduct drilling.

The three CAES projects being investigated under combined DOE-EPRI-utility sponsorship illustrate some of the property concerns. The salt-dome air-storage site located in Mississippi and being investigated by Middle South Utilities will use a cavern located 3100-4500 feet below the surface. ${ }^{(146)}$ About 100 acres over the air storage will be needed for surface activities. (147) Purchase of this land is being contemplated. The hard-rock CAES site located in Maryland and being investigated by Potomac Electric Power Co. wi 11 use a cavern about 2300 feet below the surface. (74) Surface area requirements, including land for a compensating reservoir, are estimated to be about 310 acres. (148) Purchase of the land is also being contemplated. The aquifer-based CAES system is being investigated by Public Service Indiana. Although a final test site has not been selected, it is estimated that the depth to the air storage reservoir will be about 1800 feet. (149) The land area over the air storage bubble for a 1000 MWe facility will be on the order of 2000 acres. (150) Additional property between the limits of the air-storage area and the lowest closed underground contour (the spillpoint contour) may also require protection. The investigators contemplate that a fee simple property right to the 2000 acres will be purchased and that a storage easement for the remainder of the spillpoint will be acquired.

\subsection{EXERCISE OF EMINENT DOMAIN}

The principal and preferred way for the CAES owner/operator to obtain needed property rights wi 11 be through negotiated purchase. In some cases, the party owning the desired property rights may not wish to sell, and exercise of the power of eminent domain, if available, may be needed.

States can exercise the power of eminent domain as an incident of their sovereign power. The Fifth Amendment to the U.S. Constitution requires the payment of compensation for property taken and is applicable to the states either through the Fourteenth Amendment or through provisions in state constitutions. States may delegate the power of eminent domain by appropriate legislation to 
units of local government and even to privately owned entities. All takings must be for a public use. Court interpretations of what is and is not a public use vary. However, with appropriate legislative authority, property rights condemned for a CAES project most likely would be found to be taken for a public use. Publicly owned property may even be condemned, again with appropriate legislative authority, if the proposed use is superior to the existing use of the property.

In many states, natural gas utilities have been delegated the power of eminent domain for gas storage. (151) This legislation provides an appropriate analogy and precedent for extension of the power to CAES owner/operators. The extension would require special legislation unless the owner/operator already had the necessary authority.

When property is condemned, the condemnor may generally take only the interest reasonably necessary to allow the purpose of the project to be fulfilled. For subsurface storage, an easement may be sufficient.

The condemnee in an eminent domain action is entitled to just compensation. "Just compensation" is often defined to be the cash fair-market value of the highest and best use of the property taken. Just compensation ordinarily requires that the condernnee be put in the same monetary position as he would have been had his property not been taken. This approach effectively precludes a single private owner from holding out for a "windfall" sale if his property is needed for a project.

Condemnation of underground storage space alone may be quite inexpensive if the condemnee cannot show damage. For example, in one case a natural gas transmission company was able to condemn an easement in underground strata for "no dollars. "(152) If groundwater rights are taken, compensation will ordinarily have to be paid. A variety of problems arise in water rights valuation and several approaches to valuation are available. ${ }^{(153)}$ The physical properties of the water right must first be quantified. The value of the water must then be estimated. One approach is to look at markets where water rights are traded. A second approach is to consider the value of the land with and without the water right. 
APPENDIX A

BACKGROUND INFORMATION ON GROUNDWATER LAW 


\section{APPENDIX A}

\section{BACKGROUND INFORMATION ON GROUNWATIR LAW(154)}

Four principal types of groundwater rights exist: 1) appropriative, 2) overlying, 3) prescriptive, and 4) pueblo. (155) The latter two are of limited importance. Prescriptive rights are vested rights to use a limited groundwater supply acquired after continuous water use for a period established by statute, often 7 to 10 years. Pueblo rights are the rights of communities in the southwest as successors to Spanish or Mexican pueblos to use waters naturally present within the old pueblo limits.

Appropriative groundwater rights exist in most western states. The rights are generally acquired by permit from a state water agency and are allocated on a first in time-first in right basis, as is the case with surface appropriative rights. In times of water shortage, the junior appropriator in time is the first to have his water right cut back.

Overlying rights predominate in the eastern and midwest states. The rights derive from the common (judge made) law and exist in three forms: the English rule of absolute ownership, the American rule of reasonable use, and the rule of correlative rights. The English rule of absolute ownership is analogous to the nonownership rule in oil and gas law. Under this rule the overlying landowner has unlimited access to water under his land, but does not own it until capture. Only a few states accept this rule. The American rule of reasonable use is more common and is similar to the English rule with the added provision that the water cannot be unreasonably extracted or unreasonably harm the underground aquifer. Correlative rights stem from a 1903 California case ${ }^{(156)}$ and provide that the rights of every water user are to be correlative with the rights of every other user. The correlative rights rule is not entirely limited to California. Several other states following the American rule have added a sharing requirement to the reasonable use doctrine. The reasonable use and correlative rights rules are analogous to the qualified ownership rule of oil and gas law discussed in Appendix B. 
APPENDIX B

BACKGROUND INFORMATION ON OWNERSHIP AND USE OF UNDERGROUND SPACE 


\section{APPENDIX B}

\section{BACKGROUND NFORMATION ON OMNERSHP \\ AND LE OF UNDERGROUND SPACE ${ }^{(154)}$}

Under the English common law, a surface landowner was considered to also on everything vertically upward and downward from his land. This rule first appeared in an English case in 1586, but had its origins in other law systems several hundred years earlier. ${ }^{(157)}$ As applied to air space, the rule began to break down with the coming of airplanes. The U.S. Congress in the Air Commerce Act of 1926 and the Civil Aeronautics Act of 1938 declared a public right to freedom of transit within the navigable air space. The landowner did not lose all aboveground property rights, however. In a leading 1946 case, the Supreme Court required compensation to be paid to a landowner who suffered damage to his poultry business because of low-flying government aircraft. (158) The Court stated that 'the landowner owns at least as much of the space aboveground as he can occupy or use in connection with the land."

The law for underground space has not developed to the same extent as that for aboveground, although it appears to be heading in the same direction. For example, several court cases in New York State have awarded only minimal damages to surface owners for subway tunnels constructed at considerable depth (e.g., more that $100 \mathrm{feet}$ ) under the land. (157) Another case found no invasion of property rights for a sewer 150 feet below the surface. (157) U.S. mining law generally provides that the owner of the rights to the highest point of a mineral vein owns the entire vein even if it extends beyond the horizontal boundaries of the original claim. (157) These cases support the notion that vertical ownership is not absolute, but rather is conditioned on what space the surface owner can actually utilize.

Underground storage rights in oil and natural gas law provide an interesting analogy for CAES. The current prevailing rule appears to be that gas can be stored under another's ground as long as compensation is paid. Three possible theories for relating underground oil and gas to the property rights of the surface owner have been advanced: 
1. nonownership - $\mathrm{Oil}$ and gas are incapable of ownership until reduced to possession.

2. qualified ownership - Landowners have correlative rights in an underground oil and gas reservoir.

3. ownership in place - The nature of the surface owner's interest in o il and gas is the same as for solid minerals.

All of the theories have been advanced by state courts at one time or another; however, the decisions are not always consistent. The third theory is the most common, followed by 1 and then 2 . Under theory 1 , an early Kentucky case concluded that natural gas stored under another's property was not a trespass, but that the gas was subject to capture. (160) More recent cases have rejected this view and have held that gas artificially stored underground is not subject to capture. (161) In the later instance, however, compensation must be paid to the surface and/or mineral owner for the right to store. Case law is mixed on whether the surface or mineral owner or both is entitled to payment. (162) $\mathrm{O} i \mathrm{l}$ and gas law thus seems to be developing similarly to the law of air space. Ownership of the space beneath the surface owner's land is recognized. However, the surface owner cannot interfere with a reasonable underground use such as gas storage. However, the owner is generally entitled to compensation for use of the underground space. Unlike the air space, sewer, and subway cases this is apparently true even when the surface owner cannot make effective use of the storage space. This outcome strongly suggests that someone desiring to store natural gas (and perhaps by analogy compressed air) might just as well negotiate the purchase of a storage easement if storage rights, but not surface rights, are needed.

Underground storage of water also provides an interesting analogy for the CAES concept. Underground water storage has been utilized in California for many years, and the law there is considerably more developed than in other states. (163) At least for public water agencies, the law in California now permits the storage of water underground and the right to protect and recapture the stored water. Moreover, these rights can be exercised without paying compensating overlying landowners. The most important case establishing these 
rights is Niles v. Alameda Water District. (164)

In this case, the plaintiff, Niles, sued the defendant Water District for damages caused by impairment of quarry operations due to a rising water table caused by underground water storage. The California Court of Appeal found for the Water District and based its decision on the existence of a public servitude for groundwater storage and conservation. The court also found that the storage operations were a noncompensable exercise of the District's police power. The court did suggest, however, that compensation would have been appropriate if the water level had risen above the historical water table. The Niles decision is especially remarkable because California had codified the common law rule that the surface landowner owns subsurface space. The California Civil Code (section 829) provides that "the owner of land in fee has the right to the surface and to everything permanently situated beneath or above it." Section 659 of the same Code defines land as including "free or occupied space for an indefinite distance upwards as well as downwards."

A second California case, City of Los Angeles v. City of San Fernando, (165) established the right of a public water agency to store water underground and to recapture the water later. This right exists regardless of whether prior recapture intent existed, whether the water to be recaptured can be identically traced to the water stored, or whether the storing agency actually serves the area overlying the underground basin.

In a 1971 report for the National Water Commission, one author advocated a similar result to the California cases and concluded that the law in most jurisdictions would support the result. (166) Specifically he concluded:

1. A can store water beneath $B^{\prime}$ 's land without acquiring a right to do so whether or not $A$ is a public agency. A must, however, indemnify B for damage.

2. B cannot extract the water that $A$ has stored beneath B's soil.

The two California cases provide an interesting and potentially valuable precedent for implementing the CAES concept. If the cases were to be followed and extended to air storage, a public agency (or perhaps even a private entity if the above cited author is correct) possibly could store compressed air underground and be assured of the exclusive right to recapture without compensating 
overlying landowners. There are obvious problems with relying too strongly on the analogy, however. First, there is no guarantee the result would apply to CAES. Second, compensation may have to be paid if groundwater or mineral rights are impaired. Third, the ability of the CAES owner to prevent drilling into the CAES storage medium is uncertain. Initial purchase of a storage easement would alleviate these problems. 
REFERENCES AND NOTES

1. M.A. Beckwith and D.W. Boehm, CAES Environmental Control Concerns and Program Plan, PNL-3431, Pacific Northwest Laboratory, Richland, WA June 1980.

2. A.J. Giramonti, et al., United Technologies Research Center, Hartford, CT, Technical and Economic Assessment of Fluidized Bed Augmented Compressed Air Energy Storage System, R80-954480-20, prepared for PNL and DOE, 1980.

3. S.C. Schulte and R.W. Reilly, The Economics of Compressed Air Energy Storage Employing Thermal Energy Storage, PNL-3191, Pacific Northwest Laboratory, Richland, WA November 1979.

4. "Eighty Atmospheres in Reserve," EPRI Journal, Palo Alto, CA p. 15, April 1979. "CAES R\&D Status Report," EPRI Journal, p. 48, May 1981. A description of the Huntorf plant desiann. construction., and commissioning is in 1978 Compressed Air Enerqy Storage Symposium, CONF-780599, Volume 1, DOE, January 1979.

5. "Putting Baseload to Work on the Night Shift," EPRI Journal, Palo Alto CA p. 8, April 1980.

6. 42 USCA 8311, 10 CR 503.2.

7. 46 Federal Register 22929, April 22, 1981.

8. 45 Federal Register 38302, June 6, 1980.

9. $10 \mathrm{CR} 503.38(\mathrm{a})$.

10. 10 CR 503.38(c).

11. 10 CR 503.11, 10 CR 503.16.

12. 10 OR $503.41(a)$.

13. 10 CR 503.41(a)(2)(ii).

14. 10 CR 503 Subpart D.

15. 10 CR 503 Subpart C.

16. 42 USCA 7409.

17. 40 CR Part 50 .

18. 40 CR 50.10 .

19. 44 Federal Register 52792, September 11, 1979, 40 CR 60.330. 
20. 45 Federal Register 81653.

21. 45 Federal Register 52676, 40 CFR 51,52,124. See also: S.A. Goldberg, "Source Planning Under the New PSD Regulations," Environment Reporter, Monograph No. 29, Bureau of National Affairs, Washington, D.C., November $21,1980$.

22. $40 \mathrm{CFR}$ 52.21.

23. Certain statutory sources are classified as major if they emit 100 tons or more of any pollutant. A gas turbine is not in this category.

24. NUS Corp., Rockville, MD, Preliminary Design Study of Underground Pumped Hydro and Compressed Air Energy Storage in Hard Rock, prepared for Acres American Inc., Buffalo, NY, and Potomac Electric Power Co., Washington, D.C., Table 5-5, March 1980.

25. Ibid., p. 5-8.

26. 40 CFR 52.21(b)(12).

27. 40 CER $52.21(i)(b)(k)$.

28. $40 \mathrm{CFR}$ 52.21(m)(1)(ii).

29. 45 Federal Register 3088, May 7, 1980. Regulations are scheduled to be issued in August 1981, 46 Federal Register 3408.

30. 40 CFR 52.21(m)(1)(i).

31. 40 CFR 51.24(b)(23).

32. 40 CFR 52.21(m)(1)(iii).

33. 45 Federal Reqister 52724, August 7, 1980.

34. $40 \mathrm{CER}$ 52.21(0).

35. $40 \mathrm{CER} 52.21(n)$.

36. See generally: R.H. Rosenberg and B.A. Friedman, "Air Quality and Industrial Growth: The Location of New Industrial Sources of Pollution in NonAttainment Areas," Natural Resources Lawyer, Vol. 11, No. 3, p. 523, 1979. John Quarles, "Federal Regulation of New Industrial Plants," Environment Reporter, Monograph 28, May 4, 1979, Bureau of National Affairs, Washington, D.C. Robert V. Zener, Guide To Federal Environmental Law, Practicing Law Institute, New York, New York, Chapter 1, 1981.

37. 40 CER 52.24(f)(5).

38. 33 USCA 1342. 
39. U.S. Water Resources Council, State of the States: Water Resources Planning and Management, Washington, D.C., April 1980.

40. Clean Water Act, section 301(a), 33 USCA 1311(a).

41. Acres American Inc., Columbia, MD, Design Transmittal - CAES Subtask 3CB31 Waste Treatment System, prepared for Potomac Electric Power Co., DOE, and EPRI, July 1979.

42. Clean Water Act, section 502(6), 33 USCA $1362(6)$.

43. United Engineers and Constructors Inc., A Study of CAES for the Middle South Utilities System - Topical Report No. 4 - Environmental Assessment of the Carmichael Site, Final Draft, p. 1-10, 1980.

44. 33 USCA 1362(7).

45. 40 CR 122.7, 122.60, 122.61.

46. Angus McBeth and Donald W. Stever Jr., "Federal Water Pollution Control," Environmental Law and Practice 1980, Practicing Law Institute, New York, NY, p. 26.

47. Clean Water Act, section 301(b)(2)(E).

48. 40 CF 401.16 .

49. Clean Water Act, section 301(b)(2)(F).

50. Clean Water Act, section 301(b)(2).

51. 33 CR 322, 325.

52. 40 CR 401.14 .

53. 40 CR 110.3.

54. $40 \mathrm{CR} 122.3$, U.S. V. Ashland $0 \mathrm{il}$ and Transportation Co., 504 F.2d 1317, 7 ERC 1114, (1974).

55. 40 CR 112.1.

56. $40 \mathrm{CPR} 112.3(\mathrm{~b})$.

57. 33 USCA 1288.

58. Clean Water Act, section 208(b)(2)(H).

59. Clean Water Act, section 208(b)(2)(K). 
A useful recent source of information on acquiring water for energy projects is John Muir Institute, Institutional Constraints on Alternative Water for Energy, prepared for the Los Alamos Scientific Laboratory and DOE, DOE/EV/10180-01, November 1980.

61. National Association of Regulatory Utility Commissioners, 1979 Annual Report on Utility and Carrier Regulation, Washington, D.C., Table 41, October 1980 .

62. Frank P. Grad, Treatise on Environmental Law, Matthew Bender, New York, NY, p. 11-138, 1980 .

63. John Muir Institute, reference 60, p. 121 . A state by state analysis is in Grad, Ibid., section $11.03(3)$.

64. 42 USCA 4321.

65. 16 USCA 661 .

66. 16 USCA 1451.

67. Council on Environmental Quality, Environmental Quality 1979, Washington, D.C., USGPO, Table 8-1, December 1979.

68. 42 USCA 300 et seq., Public Law 93-525.

69. SDWA, section $1421(b)$.

70. $40 \mathrm{CFR}$ 122.33, $40 \mathrm{CFR}$ 146.1(b).

71. 45 Federal Register 33436.

72. $40 \mathrm{CER} 122.31(\mathrm{c})$.

73. $40 \mathrm{CER} 122.3,146.3$.

74. Acres American Inc., Buffalo, NY, Preliminary Design of Underground Pumped Hydro and Compressed Air Energy Storage in Hard Rock Volume IX Design Approaches CAES, prepared for Potomac Electric Power Co., February 1980.

75. $40 \mathrm{CFR}$ 146.5.

76. 40 CFR 146.51.

77. 40 CFR 146.5(e).

78. $40 \mathrm{CFR}$ 122.37(a)(4).

79. $40 \mathrm{CFR}$ 122.38(a).

80. $40 \mathrm{CFR}$ 122.9(c). 
81. 40 CFR 146.52.

82. An underground source of drinking water means any portion of an aquifer which supplies drinking water or in which the groundwater contains fewer than 10,000 mg/1 total dissolved solids. $40 \mathrm{CFR}$ 122.3. An aquifer that cannot feasibly be used as an underground source of drinking water can potentially be exempted under the criteria found at $40 \mathrm{CFR}$ 146.4.

83. $40 \mathrm{CER}$ 122.34.

84. NUS Corp., Rockville, MD, Integrated Environmental and Safety Assessment of Selected Mechanical Energy Storage Systems, prepared for EPRI, 1981.

85. Clean Water Act, section 301(a).

86. A sumary of state requirements, regulatory agencies, and citations to appropriate state code and regulation sections is in J.D Ritchey and J.D. Miller, National Water Well Association, Compendium of State laws and Requlations Affecting Water Well Drilling, Worthington, Ohio, 1979.

87. National Water Well Association, A Manual of Laws, Regulations, and Institutions for Control of Groundwater Pol lution, NTIS No. PB-257 808, prepared for EPA, June 1976, p. 11-94.

88. 42 USCA $4322(2)(c)$.

89. 40 CFR 1508.9.

90. $40 \mathrm{CFR}$ 1501.5(c).

91. 40 CFR 1501.5(b), 1506.2.

92. 40 CER 1506.2.

93. A summary of state EIS requirements as of June 1, 1979 is in reference 67, Table 10-3.

94. $40 \mathrm{CFR}$ 1501.5(e),(f).

95. 29 CFR 1910.95, 1926.52.

96. A sumary of noise impacts is in reference 84 .

97. A sumary of state regulation is in reference 62, p. 5.62.

98. M.C. Krupka, et al., Assessment of Environmental Control Technologies for Energy Storage Systems, LA-8308-MS, Los Alamos Scientific Laboratory, Los Alamos, NM, p. 43, April 1980.

99. Reference 43 , p. $1-5$. 
100. 40 CR 146.5(c)(2).

101. $40 \mathrm{CP} 122.51(\mathrm{c})$.

102. 40 CR 125 Subpart M, 45 Federal Reqister 65953, October 3, 1980.

103. 40 CR 125.123(d)(2).

104. 33 USCA 1401.

105. 40 CR 221.1(f).

106. 42 USCA 6901-6987.

107. See: 40 CF 260 Appendix I, Figure 2.

108. 30 USCA 801 et seq..

109. 30 USCA 803.

110. 30 USCA $802(h)(1)$.

111. KW. Winterholler, "MSHA, What to do With the Inspector," 25 Rocky Mountain Law Institute, p. 8-3, Matthew Bender, New York, NY, 1979.

112. See: J.W. Nebgen and M.K Snyder, Midwest Research Institute, Kansas City, MO, CAES Environmental Impacts of Mined Waste Rock, prepared for PNL and DOE, August 1979.

113. Reference 84 .

114. 40 CR $257.1(\mathrm{c})(2)$.

115. 40 CR 261.4(b)(3).

116. 45 Federal Register 76620, November 19, 1980.

117. 40 CR 241.100(a).

118. A good source of information on state law, particularly western states, affecting mined waste disposal is George E. Reeves and Stephen D. Alfers, "Dumps and Tailings," 23 Rocky Mountain Mineral Law Institute 419, Matthew Bender and Co., New York, NY, 1977.

119. California Public Resources Code, section 2735.

120. California Administrative Code, Title 14, section 3504(e).

121. Charles F. Reusch, "Federal Power Commission Regulation of CAES Projects," proceedings of the Workshop on CAES system. December 18, 19 1975, ERDA-76-124, CONF 75-1242, p. 394. 
122. 16 USCA 817.

123. Chemehuev Tribe of Indians v. FPC, 420 U.S. 395, 422-424, 95 S.Ct. 1066, (1975).

124. Public Service Co. of New Mexico obtained a declaratory order that a pumped hydro facility, utilizing groundwater for its water supply, did not require a license under the Federal Power Act. The petition was filed May 15, 1979 and the order issued March 21, $1980 . \quad$ Docket No. EL7918.

125. 7 Minnesota Code of Agency Regulation 1.218(a).

126. Sargent and Lundy, Chicago, IL, Compressed Air Energy Storage - Preliminary Design and Site Development Program in an Aquifer, Task 2, p. 5-5, prepared for Public Service Indiana, EPRI, and DOE, December 1980.

127. 40 CR 149.10 .

128. 40 CR $149.2(\mathrm{~g})$.

129. 40 CR 141.

130. Council on Environmental Quality, Eleventh Annual Report on Environmental Quality, USGPO, p. 98, December 1980.

131. EPA, Groundwater Protection, Washington, D.C., p. 21, November 1980.

132. EPA, Proposed Groundwater Protection Stratesy, Washington D.C., November 1980.

133. J.T.B. Tripp and A.B. Jaffe, "Preventing Groundwater Pollution: Towards a Coordinated Strategy to Protect Critical Recharge Zones," Harvard Environmental Law Review, Vol. 3, 1979, p.27.

134. a. Reference 1.

b. c. Hampson et al., International Research and Technology Corp., McLean, VA, Cavity Degradation Risk Insurance Assessment, TR20700/1, prepared for DOE, 1980.

c. J.A. Stottlemyre and W.V. Loscutoff., PNL. 'Environmental Concerns for Compressed Air Energy Storage in Porous Media Systems," 1978 Compressed Air Energy Storaqe Symposium Proceedings, CONF-780599, p. 667, January 1979.

135. See: C. Morris and C.R. Morris Jr., Morris on Torts, Second Edition, The Foundation Press, Mineola, NY, p. 231, 1980. W.L Prosser, Law of $\underline{\text { Torts, }}$ Fourth Edition, West Publishing Co., St. Paul, MN, Chapter 13, 1971.

136. Green v. General Petroleum Corp., 270 P. 952 (1928). 
137. Prosser, reference 135.

138. WH Rodgers, Environmental Law, West Publishing Co., chapter II, 1977.

139. Ibid., section 2.13 .

140. Hampson, reference 134(b), p. 1-5.

141. Reference 126, p. 0-3.

142. Restatement of the Law of Torts 2d, American Law Institute Publishers, St. Paul, MN.

143. Reference 126, p. D-1.

144. Newsweek, December 1, 1980, p. 42.

145. Most state courts consider o il and gas rights to be included in a grant of mineral rights. In this study, mineral rights are also assumed to include oil and gas rights.

146. Reference 43, Figure 1.3-1.

147. Reference 43, p. 3-1.

148. Reference 24, p. 5-8.

149. Reference 126, p. 4-9.

150. Reference 126, p. 4-79.

151. A 1966 article identified 20 states that had delegated this authority. R.R. Scott, 'Underground Storage of Natural Gas: A Study of Legal Problems," 19 Oklahoma Law Review 66.

152. Midwestern Gas Transmission Co. V. Mason, 201 N.E.2d 379, (1964).

153. J.F. Ross, "Valuation of Water Rights for Acquisition, Condemnation, and Taxation Purposes," Rocky Mountain Mineral Law Institute, Vol. 18,

p. 563, Matthew Bender, New York, NY, 1973.

154. Much of the discussion that follows is adapted from P.L. Hendrickson, Legal and Regulatory Issues Affecting the Aquifer Thermal Energy Storage Concept, PNL-3437, Pacific Northwest LAboratory, Richland, WA, October 1980 .

155. N.W. Thorson, "Storing Water Underground: What's the Aquifer?," Nebraska Law Review, Vol. 57, No. 3, p. 581, 1978.

156. Kate v. Walkinshaw, 74 P. 766 (1903). 
WA Thomas, "Ownership of Subterranean Space," Underground Space, Vol. 3, No. 4, p. 155, Pergamon Press, 1979. Also printed in T. Stauffer (editor), Underground Utilization: A Reference Manual of Useful Works, Vol. 7: Regulation and Policy in Use of Underground Space, University of Missouri, Kansas City, MO, 1978.

158. United States v. Causby, 328 U.S. 256 (1946).

159. H. Williams and C. Meyers, $0 \mathrm{i} \mid$ and Gas Law, section 203, Matthew Bender, New York, NY.

160. Hammonds v. Central Kentucky Natural Gas Co., 75 S.W.2d 205 (1934).

161. Ellis v. Arkansas Louisiana Gas Co., 450 F. Supp. 412 (E.D. Okla. 1978). Lone Star Gas Co. V. Murchison, 353 S.W.2d 870 (1962).

162. Reference 159, section 222.

163. See generally: V.E. Gleason, "Water Projects Go Underground," Ecology Law Quarterly, Vol. 5, No. 4, p. 625, 1976. V.E. Gleason, "The Legalization of Groundwater Storage," Water Resources Bul letin, Vol. 14, No. 3, p. 532, June 1978.

164. 37 Cal. App. 3d 924 (1974).

165. 537 P.2d 1250 (1975).

166. C.E. Corker, Groundwater Law, Management and Administration, NTIS No. PB-205 527, p. 184, (1971). 


\section{DISTRIBUTION}

No. of

Copies

\section{OFSITE}

Acres American, Inc.

Attn: D. Willett

Liberty Bank Building

Main at Court

Buffalo, NY 14202

Acres American, Inc.

Attn: M. J. Hobson

The Clark Building

Suite 329

Columbia, MD 21044

Bechtel National Inc.

Attn: W. Stevens (50/20/B37)

Res \& Eng.

P.0. Box 3965

San Francisco, CA 94119

Black and Veatch

Attn: D. R. Bervig

1500 Meadow Lake Parkway

P.O. Box 8405

Kansas City, MO 64114

Central Illinois Public Service Co.

Attn: A. H. Warnke

Vice President Power Supply

607 East Adams Street

Springfield, IL 62701

Commonwealth Edison Co.

Attn: T. J. Maiman

Sta. Mech. Engr. Dept. Mgr.

36 fN West

P.O. Box 767

Chicago, IL 60690

Commonwealt h Edison Co.

Attn: D. E. DeViney

1319 South First Avenue

Maywood, IL 60153
No. of

Copies

27 DOE Technical Information Center

5 U.S. Department of Energy

Attn: S. Strauch

Office of Energy Systems Res. (CS-66)

Forrestal Building (Room 16-080) 1000 Independence Ave., S.W.

Washington, DC 20585

U.S. Department of Energy

Attn: J. H. Swisher

Office of Energy Systems Res. (CS-66)

Forrestal Building (Room 16-080)

1000 Independence Ave., S.W.

Washington, DC 20585

U.S. Department of Energy

Attn: J. Gahimer

Office of Energy Systems Res. ( CS-66)

Forrestal Building (Room 16-080)

1000 Independence Ave., S.W.

Washington, DC 20585

U.S. Department of Energy

Attn: A. A. Churm

Chicago Patent Group

Chicago Operations Office

9800 South Cass Avenue

Argonne, IL 60439

U.S. Department of Energy

Attn: $\mathbb{P}$ Demos

Chicago Operations Office

9800 South Cass Avenue

Argonne, IL 60439

5 U.S. Department of Energy

Attn: B. Gallagher

0 fice of Energy Systems Res. (CS-66)

Forrestal Building (16-080)

1000 Independence Ave., S.W.

Washington, DC 20585 
No. of

Copies

U.S. Department of Energy

Attn: J. Mathur

Division of Environmental

Safety and Engineering

MS-E201, Germantown

Washington, DC 20545

U.S. Department of Energy

Library

Mail Station G-043

Washington, DC 20585

U.S. Department of Energy

Library, Attn: R. F. Kimberlin

Room 1223

Washington, DC 20585

U.S. Department of Energy

Attn: L. J. Rogers

Division of Generation and

Storage Applications

Office of Electric Energy Sys.

12 \& Pennsylvania, M/S 3344

Washington, DC 20585

EFE, Inc.

Attn: Brian Borofka

763 New Ballas Road South

St. Louis, MO 63141

Electric Power Research Instit.

Attn: R. B. Schainker

P.O. Box 10412

3412 Hillview Avenue

Palo Alto, CA 94304

Electric Power Research Instit.

Attn: A. Ferreira

c/O NEPLAN

174 Brush Hill Avenue

West Springfield, MA 01089

Harza Engineering Company

Attn: A. H. Barber

Director of Marketing

150 S. Wacker Drive

Chicago, IL 60606
No. of

Copies

I11inois Power Company

Attn: Mr. G. E. Huck

Manager of Planning

500 South 27th St.

Decatur, IL 62525

Lawrence Berkeley Laboratory

Attn: Library

University of California

Bldg. 50, Room 134

Berkeley, CA 94720

2 Lawrence Livermore Laboratory

Attn: Tech. Info. Dept., L-3

University of California

P.O. Box 808

Livermore, CA 94550

Lawrence Livermore Laboratory

Attn: T. Barlow

P.O. Box 808

Livermore, CA 94550

Los Alamos Scientific Laboratory

Attn: Jim Blacic

G-6-LASL-Stop 978

P.O. Box 1663

Los Alamos, NM 87545

Louisiana State University

Attn: R. L. Thorns

Institute for Environmental Studies

Room 42, Atk inson $\mathrm{Hall}$

Baton Rouge, LA 70803

Marchwood Engineering Labs

Attn: I - Glendenning

Head of Long-Term Studies

Southampton, England

Massachusetts Institute of Tech.

Attn: J. L. Nash-Webber

Energy Lab

Cambridge, MA 02139 
No. of

Copies

Middle South Services

Attn: L. A. Wilson

Advanced Energy Program Section

Box 6100

New Orleans, LA 70161

National Science Foundation

Division of Advanced Energy

Research and Technology

Room 1140

1800 G Street, M

Washington, DC 20550

Northern Research \& Eng. Corp.

Attn: Jerry 0. Melconian

39 Olympia Avenue

Woburn, MA 01801

PB-KBB Inc.

Attn: J. Istvan

P.O. Box 19672

Houston, TX 77024

Potomac Electric Power Co.

Attn: P. E. Schaub

1900 Pennsylvania Avenue

Washington, DC 20006

Public Service of Indiana

Attn: T. W. McCafferty

1000 E Main Street

Plainfield, IN 46168

$\mathrm{Re} / \mathrm{Spec}$ Inc.

Attn: A F. Fossum

P.O. Box 725

Rapid City, SD 57701

Sandia Laboratories

Attn: Tech. Library Div. 3141

Albuquerque, NM 87185

Sandia Laboratories

Attn: H M. Dodd

Organization 5743

Albuquerque, M 87115
No. of

Copies

Sandia Laboratories

Attn: R. 0. Woods

Organization 4715

Albuquerque, M 87115

Sandia Laboratories

Attn: William G. Wilson

P.O. Box 969

Organization 8453

Livermore, CA 94550

Sargent and Lundy Engineers

Attn: Mr. W. C. Walke

Project Manager

55 East Monroe Street

Chicago, IL 60603

Soyland Power Cooperative, Inc.

Attn: Royal B. Newman

P.0. Box A1606

Decatur, IL 62525

Tennessee Valley Authority

Energy Research Section

1360 Commerce Union Bank Bldg.

Chattanooga, $\mathbb{T N} 37401$

Tennessee Valley Authority

Attn: Gerald Phillips

1150 Chestnut, Tower 2

Chattanooga, $\mathbb{T N} 37401$

$\mathbb{R} W$ Energy Systems Group

Attn: E. Berman

Technical Library

7600 Colshire Drive

McLean, VA 22101

Union Electric Co.

Attn: E. M. Mabuce

Manager - App 1ied Research

Corporate Planning Dept.

P.O. Box 149

St. Louis, MO 63166 
No. of

Copies

United Technologies Research Center

Attn: R. D. Lessard

Silver Lane

East Hartford, CT 06108

University of California

Attn: T. L. Brekke

Department of Civil Engineering

1847 Yosemite Road

Berkeley, CA 94707

University of Massachusetts

Attn: 0. C. Farquhar

Dept. of Geology \& Geography

Morrill Science Center

Amherst, MA 01003

University of Michigan

Attn: Donald L. Katz

Dept. of Chemical Engineering

2042 E. Engr. Bldg.

Ann Arbor, MI 48109

University of Wisconsin

Attn: H. J. Pincus

Dept. of Geological Sciences

Sabin Hall and Greene Museum

P.O. Box 413

Milwaukee, W I 53201

Westinghouse Electric Corp.

Attn: W. F. Kobett

CAES Project Manager

Combustion Turbine Sys. Div.

Long Range Develop-Lab 100

P.O. Box 251

Concordville, PA 19331

Westinghouse Electric Corp.

Attn: D. Ayers

Manager, Fluid Systems Laboratory

1291 Cumber 1 and Avenue

West Lafayette, IN 47906
No. of

Copies

QNSITE

2 DOE Richland Operations Office

D. K. Jones

H. E. Ransom

50 Pacific Northwest Laboratory

R. D. Allen

M. A Beckwith (5)

D. E. Deonigi

T. J. Doherty

J. R. Eliason

R. L. Erikson

P. L. Hendrickson (15)

L. D. Kannberg (10)

J. E. Minor

J. R. Raymond

R. W. Reilly

J. A Stottlemyre

A. M. Sutey

L. E. Wiles

T. L. Willke

F. R. Zaloudek

Technical Information (5)

Publishing Coordination KE(2) 